\title{
Aspirations, Human Capital Investment, and the Intergenerational Transmission of Poverty in Indonesia
}

\author{
Sung Soo $\operatorname{Lim}^{1} \cdot$ Jongwook Lee ${ }^{2}$
}

Accepted: 1 November 2021 / Published online: 15 November 2021

(C) The Author(s) 2021

\begin{abstract}
This study investigates the effect of parental aspirations gap on children's educational attainment between 2007 and 2014, using two waves of Indonesian Family Life Survey data. The aspirations gap is measured by the difference between one's future reference point and his or her current life evaluation reported by each household head and spouse. The results show that boys whose fathers report a moderate level of the aspirations gap achieve substantially longer schooling years than the mean level of their same age cohort. Furthermore, the relationship is found to be inversely U-shaped, implying that an excessive aspirations gap discourages investment in children's human capital. An increasing aspirations gap of parents is also found to impede the educational attainment of children in poor families, which are more vulnerable to shocks that are found to increase the gap. Overall, the results of this paper shed light on the role of parental aspirations gap in the link between socioeconomic status of family and educational outcomes of children in Indonesia, where the gap of the poor is found to increase faster than the rich.
\end{abstract}

Keywords Aspirations $\cdot$ Schooling $\cdot$ Human capital investment $\cdot$ Poverty trap $\cdot$ Indonesia

\section{Introduction}

The relationship between socioeconomic status of family and educational outcomes of children is one of the most robust patterns in educational scholarship. Yet there have been considerable debate and disagreement on the causes and mechanisms of this relationship. (Bowles \& Gintis, 1976, 2002; Duncan et. al., 1994; Herrnstein, 1995; Duncan \& Brooks-Gunn, 1997; Lareau, 2000, 2011; Ma \& Schapira, 2017). This paper investigates

Jongwook Lee

jongwooklee@snu.ac.kr

Sung Soo Lim

s197@calvin.edu

1 Department of Economics, Calvin University, 1740 Knollcrest Circle SE, Grand Rapids, MI 49546, USA

2 Department of Agricultural Economics and Rural Development, Seoul National University, 1 Gwanak-ro, Gwanak-gu, Seoul 08826, Republic of Korea 
the effect of wellbeing aspirations of household heads and spouses on the investment in their children's human capital, which has serious implications for the future welfare of the poor (Jacoby \& Skoufias, 1997). The investment in human capital is an important tool for reducing poverty, but aspirations failure of the poor household heads may lead to underinvestment in their children's education. Despite the significance in intergenerational transmission of poverty, few studies, if any, have investigated the link between poverty and schooling of children from the perspective of aspirations failure especially in the context of developing countries.

One variable of special interest in this study is the aspirations gap, which is defined by a difference between one's future reference point and current life evaluation, available from the Indonesian Family Life Survey (IFLS) data (2007 and 2014). Consistent with Ray (2006) and Genicot and Ray (2017), we assume that the future reference points are influenced by individual circumstances and by the income distribution of one's similar or attainable individuals. We also conjecture that it is this gap rather than aspirations per se or the future reference point alone that affects the future-oriented decisions of households. ${ }^{1}$ For instance, individuals whose future reference points are not very far away from their current standards of living have little incentive to raise those standards, which in turn may affect their investment in children's human capital. An excessive gap may also lead to aspirations failure due to frustrations (Genicot \& Ray, 2017). Thus, aspiration failure may occur due to the absence of a critical mass of comparable people in one's neighborhood who are significantly better off. Or it may be caused by an increasing income inequality in the person's community. Given that returns to schooling remain low in less developed countries, the excessive as well as the insufficient aspirations gap of parents may lead to underinvestment in children's human capital in those countries. ${ }^{2}$

On the other hand, the poor are, more often than not, characterized to have internal constraints such as lack of aspirations or willpower. ${ }^{3}$ Unlike the general claim on aspirations and poverty, however, our sample data show that the bottom $10 \%$ and $25 \%$ of household heads and their spouses in the household asset distribution have higher aspirations gaps than the top $10 \%$ of households in both 2007 and 2014 (Figs. 1, 2). Interestingly, the difference becomes much larger in 2014 between the poor and the rich. Yet, the growth rates of both absolute and relative education years of children are much lower in the poor households between 2007 and 2014 (Fig. 3). ${ }^{4}$ Motivated by these seemingly incongruent findings, we attempt to answer three questions in this study: (1) Does the higher aspirations gap of parents lead to a greater investment in children's human capital? (2) Does an increasing aspirations gap of parents lead to a greater investment in children's human capital? (3) Does an increasing aspirations gap of the poor parents lead to a more adverse impact on children's education?

The results of our study show that an excessive aspiration gap of the household head, ceteris paribus, is associated with a lower educational attainment of boys between 2007

\footnotetext{
1 This conjecture, initially proposed by (Ray, 2006), is also in line with the literature on reference points (Kahneman and Tversky, 1979; Kőszegi and Rabin, 2006; Shalev, 2000).

${ }^{2}$ Returns to schooling remain low in Indonesia compared to other Asian and less developed countries (Purnastuti et al., 2015).

3 According to the World Values Survey, $60 \%$ of Americans believe that the poor are lazy or lack of willpower, and over $70 \%$ of people do not believe the poor are trapped in poverty (Glaeser and Sacerdote, 2001).

${ }^{4}$ See Sect. 3.2 for more information about the relative education years.
} 


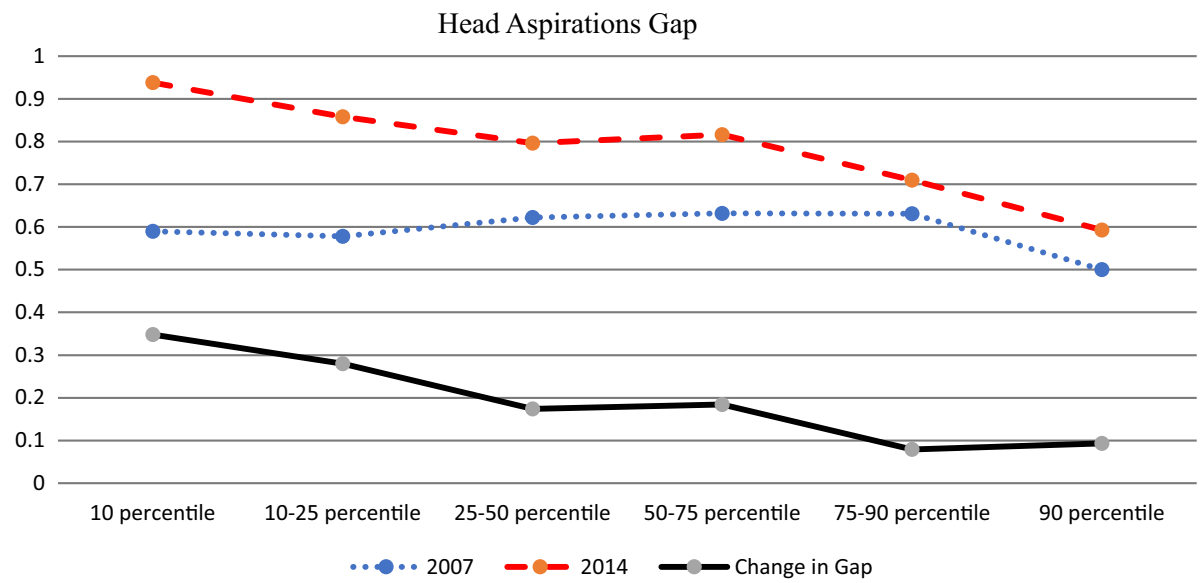

Fig. 1 Aspirations gap by household wealth levels: Head

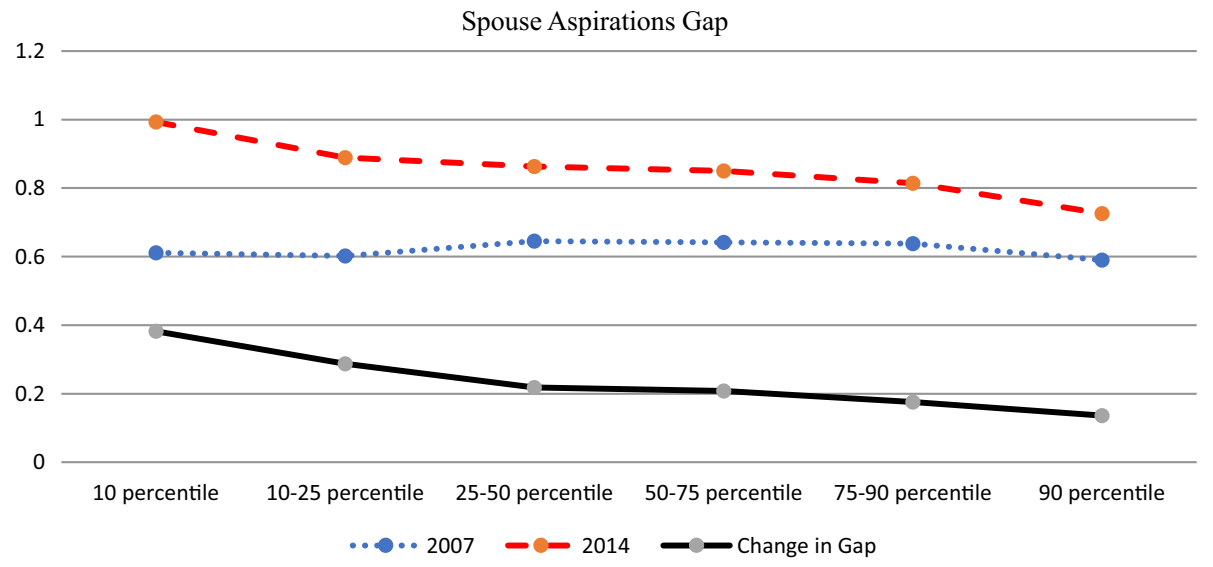

Fig. 2 Aspirations gap by household wealth levels: Spouse

and 2014. A moderate aspirations gap, in contrast, is positively associated with the growth of both absolute and relative education years of boys. Furthermore, the increase in parental aspirations gap appears to have adverse effects on schooling of children in only poor households. Overall, the results of this paper shed light on the role of parental aspirations gap in the well-established link between socioeconomic status of family and educational outcomes of children.

The rest of the paper proceeds as follows. Section 2 presents the related literature. Section 3 presents institutional setting and an overview of the data source used in this study. It also presents and explains two main variables of interest, the aspirations gap and schooling of children. Section 4 discusses the methodology and model specifications employed in this paper. The estimations results are presented and discussed in Sect. 5. Finally, Sect. 6 concludes by considering the policy implications of the results. 


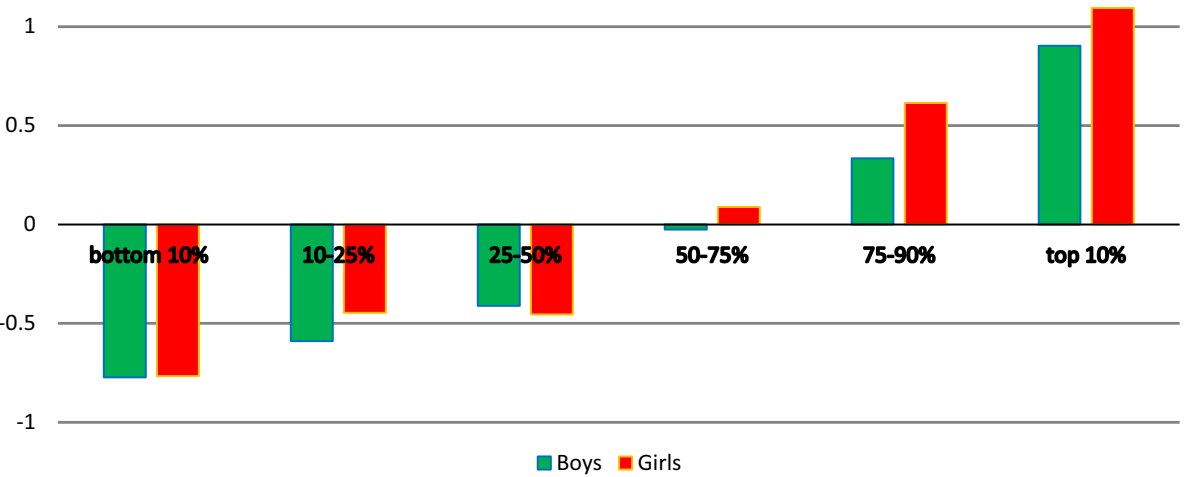

Fig. 3 Change in relative educational level of children by household asset values. Note: The relative educational level of each child was derived from the mean completed schooling years of his or her age cohort in 2007 and 2014.

\section{Related Literature}

In the neoclassical economic analysis of poverty, decision-making of the poor is shaped only by structural constraints that poverty imposes. Investment decisions of the poor, in this framework, are mainly affected by external resource constraints, and persistent poverty is driven by constraints that are external to the individuals. Such constraints include credit or insurance market imperfections (Loury, 1981; Banerjee \& Newman, 1991, 1993; Galor \& Zeira, 1993; Ranjan, 2001; Dercon \& Christaensen, 2011; Carter \& Lybbert, 2012), imperfect matching and information (Kremer, 1993), corruption and institutional failures (Shleifer \& Vishny, 1993; Bardhan, 1997), geography (Bloom et al., 1998), environmental degradation (Dasgupta et al., 2005), health and malnutrition (Dasgupta \& Ray, 1986; Strauss \& Thomas, 1998), neighborhood effects (Durlauf, 2004; Hoff and Sen, 2005), and the kin system (Sen, 2006).

In contrast, an anthropologist Arjun Appadurai (2004) argued that the poor may lack the capacity to aspire. Accordingly, the future-oriented logic of development could help the poor find the resources required to contest and alter the conditions of their own poverty. A growing economic literature also addresses the role of aspirations in persistent poverty and inequalities of societies. Recent theoretical developments and some empirical evidence indeed support the idea that failure of aspirations may be reciprocally linked to a self-sustaining trap of poverty and income inequality (Dalton et al., 2016; Pasquier-Doumer \& Brandon, 2015; Chivers, 2017; Genicot \& Ray, 2017). For instance, some studies suggest that the poor may not make future-oriented decisions to improve their wellbeing unless they see a feasibly higher level of wellbeing in the future than their current status (Appadurai, 2004; Dalton et al., 2016; Macours \& Vakis, 2014; Ray, 2006). According to Ray (2006), aspirations are born in a social context and future-oriented behaviors of individuals such as investment decisions are supposed to be affected by the aspirations gap rather than by aspirations per se. Genicot and Ray (2017), founded on this idea, formally develop a theory in which a failure to invest may occur due to a lower aspirations gap or frustration 
that results from an excessively large aspirations gap. The model implies that poverty and income inequality may bring about a vicious cycle in which a low or an excessive level of the aspirations gap inhibits future-oriented economic behavior such as human capital investment, although to date there exists little empirical evidence to support this link. Our paper, using the aspirations gap of household heads and spouses obtained from two waves of Indonesian Family Life Survey data (2007, 2014), finds empirical evidence in line with this socially-determined aspirations theory. Furthermore, unlike the previous studies on aspirations and education of children (Chiapa et al., 2012; Oketch et al., 2012; Galab et al., 2013; Macours \& Vakis, 2014; Ross, 2017; Janzen et al, 2017), we examine the differential effects of the increasing aspirations gap on schooling of children in poor and rich households, controlling for child fixed effects. The aspirations gap may change due to an increasing income inequality as well as health shocks and natural disasters, to which the poor are more vulnerable. ${ }^{5}$ The results of our study present empirical evidence that poverty and income inequality may lead to underinvestment in children's human capital via a channel of the increasing aspirations gap, resulting in intergenerational transmission of poverty.

This paper also contributes to the literature that examines a gender bias in schooling of children. This issue is far from being trivial as gender inequality in education and access to resources may prevent reductions in fertility, child mortality, and expansions in education of the next generation (Klasen, 2002; Murthi et al., 1995; Thomas, 1990). In fact, there are large gender discrepancies in education, particularly in South Asia, the Middle East and North Africa, and Sub-Saharan Africa. Among these areas, gender bias is believed to be particularly acute in South Asia (Behrman, 1992; Miller, 1997; Sen, 1990), where the bias within families may be attributed to the greater pecuniary returns that sons provide to their parents relative to daughters in the region. Without such a gender bias, assuming that aspirations moderately above the current level of wellbeing encourage future-oriented economic behavior, we should see no difference in the effect of the aspirations gap on schooling of boys and girls.

The results of our paper show evidence for a gender bias in child education in Indonesia.

On the other hand, resource transfers from parents to children are explained in a few ways in the literature. According to an altruistic model, parents may invest in children's human capital because they care about the children's well-being and not because they expect something in return (Becker et al., 1990). In an alternative model, parents may investment in children's human capital either implicitly or explicitly motivated by the amount of transfer anticipated from children during their old-age (Raut, 1990; Raut \& Tran, 2005). In particular, according to a two-sided altruism model, parents invest in children's human capital out of benevolence, anticipating that children will also voluntarily reciprocate with resource transfers to parents in old age. For instance, using Indonesian data, Frankenberg, Lillard, and Willis (2002) found that transfers from children to parents are positively correlated with children's education level, which suggests that parental educational investment in children is motivated by parental old age security in Indonesia. While the results of our study do not provide direct evidence for these models, the differential effects of the parental aspirations gap on schooling of boys and girls cast doubt on the validity of the pure altruistic model in that sons typically take care of old parents in South Asia.

\footnotetext{
${ }^{5}$ For instance, chronic illness or long-term illness can increase the aspirations gap of adults and lead to frustration and deterioration in subjective wellbeing (Lim, 2019).
} 


\section{Institutional Setting and Data}

The Indonesian education system is the fourth largest in the world with more than 50 million students, 3 million teachers, and 300,000 schools. Indonesia's public school structure conforms to a 6-3-3 pattern, that is, six years of primary, three years of middle school, and three years of upper secondary studies. All citizens must undertake the twelve years of compulsory education. Nevertheless, in 2011, the net enrolment rate dropped from $77.71 \%$ in lower secondary education to $57.74 \%$ in upper secondary education, showing a sizable loss of students from the school system (ASEAN, 2014). Students pay fees only in high school, but, even with the free education, there are other user fees charged at public primary and junior secondary schools. The user fees have been reduced especially for the poor in the post-Suharto period after the resignation of the president Suharto in 1998, but they have not been eliminated (Rosser \& Joshi, 2013).

The quality of education is another concern as 55 percent of Indonesians who finish their education are functionally illiterate, compared with Vietnam (14 percent) and the OECD countries (20 percent). ${ }^{6}$ In 1980, Indonesians 25 years and older had, on average, less than 4 years of schooling. Since then, the mean years of schooling had doubled to 8 years in 2013 (Barro \& Lee, 2013). Our sample data show that the mean education of household heads is slightly greater than 9 years in 2013 (Table 1). On the other hand, there have been growing differences in test scores and education years between students in poor households and those in rich households (World Bank, 2018). As of 2015, 10.9\% of population were living below the national poverty line. The Gini index, as of 2014, was 39.5, showing a significant increase in income inequality compared to a decade ago (32.7) (World Bank, 2017).

This paper attempts to shed light on the channel through which poverty is transmitted to the next generations using two waves (2007 and 2014) of longitudinal survey data from the Indonesian Family Life Survey (IFLS), a high-quality survey of individuals, households, and communities. The survey contains information from more than 10,000 households representing about $83 \%$ of the Indonesian population, those who live in 13 of the nation's 26 provinces. The IFLS collected a broad array of demographic, socioeconomic, and health information while capturing the cultural and socioeconomic diversity of Indonesia. The reinterview rates of the original households (IFLS1) in IFLS4 (2007) and IFLS5 (2014) were $93.6 \%$ and $92 \%$, respectively, and the risk of bias due to nonrandom attrition is very low in studies using the data. This paper uses a sample of children between 6 and 15 years old as of 2007 and those who were also identified in the 2014 survey. ${ }^{7}$ The full sample used in this study consists of 1868 children, 1135 households, and 360 communities.

\subsection{The Measure of the Aspirations Gap}

One key variable of interest in this paper is the aspirations gap of household heads $\left(A^{h}\right)$, which is the difference between household heads' current level of subjective wellbeing $\left(S W_{c}^{h}\right)$ and their reference level of wellbeing in five years later $\left(S W_{r}^{h}\right)$ as follows. ${ }^{8}$

\footnotetext{
6 According to the definition of The World Bank, functionally illiterate people are the ones who are not equipped with the skills necessary to enter successfully into the labor market.

7 IFLS has information on education history of children younger than 15 .

8 The value the aspirations gap may be negative in case the current level of subjective wellbeing is unexpectedly higher than an individual's long-term reference level and thought to be only temporary.
} 
Table 1 Descriptive statistics of the sample

\begin{tabular}{|c|c|c|c|c|c|}
\hline \multirow{2}{*}{$\begin{array}{l}\text { Abbreviation } \\
\text { Dependent variables }\end{array}$} & & \multicolumn{2}{|l|}{2007} & \multicolumn{2}{|l|}{2014} \\
\hline & & Mean & SD & Mean & $\mathrm{SD}$ \\
\hline Absolute education year & $\begin{array}{l}\text { Absolute education years of children in the } \\
\text { sample }\end{array}$ & 4.227 & 2.092 & 10.20 & 2.444 \\
\hline Relative education year: & $\begin{array}{l}\text { Relative education years compared to the } \\
\text { same age cohort }\end{array}$ & 0.043 & 1.062 & 0.014 & 2.291 \\
\hline Children & Boys and girls & & & & \\
\hline Boys & Boys only & 0.132 & 1.046 & 0.164 & 2.229 \\
\hline Girls & Girls only & -0.041 & 1.070 & -0.128 & 2.338 \\
\hline 90 percentile & $\begin{array}{l}90 \% \text { of boys and girls are below this relative } \\
\text { education }\end{array}$ & 0.93 & & 2.29 & \\
\hline 75 percentile & $\begin{array}{l}75 \% \text { of boys and girls are below this relative } \\
\text { education }\end{array}$ & 0.63 & & 1.41 & \\
\hline 50 percentile & $\begin{array}{l}50 \% \text { of boys and girls are below this relative } \\
\text { education }\end{array}$ & -0.07 & & 0.70 & \\
\hline 25 percentile & $\begin{array}{l}25 \% \text { of boys and girls are below this relative } \\
\text { education }\end{array}$ & -0.49 & & -1.59 & \\
\hline 10 percentile & $\begin{array}{l}10 \% \text { of boys and girls are below this relative } \\
\text { education }\end{array}$ & -1.27 & & -3.30 & \\
\hline \multicolumn{6}{|l|}{ Control Variables } \\
\hline \multicolumn{6}{|l|}{ Individual } \\
\hline Age & Age of a child & & & 17.81 & 2.020 \\
\hline First child & 1 if yes & & & 0.335 & 0.472 \\
\hline Child health & $1=$ very healthy, $4=$ very unhealthy & 1.923 & 0.465 & 1.886 & 0.608 \\
\hline Gender & 1 if male & & & 0.551 & 0.532 \\
\hline \multicolumn{6}{|l|}{ Family } \\
\hline Age of household head & Age of household head & & & 50.51 & 11.78 \\
\hline Aspirations gap of head & $\begin{array}{l}\text { Gap between current wellbeing and that of } \\
\text { five year later }\end{array}$ & 0.678 & 0.778 & 0.901 & 1.061 \\
\hline Subjective wellbeing & $\begin{array}{l}\text { Current subjective wellbeing }(0=\min \text {, } \\
6=\max )\end{array}$ & 3.012 & 0.942 & 2.853 & 0.784 \\
\hline Head's education & Level of education $(1=\min , 4=\max )^{1}$ & & & 2.117 & 1.105 \\
\hline Spouse's education & Level of education $(1=\min , 4=\max )$ & & & 1.906 & 1.019 \\
\hline Number of children & Number of children under 15 & 2.697 & 1.097 & 1.387 & 1.185 \\
\hline Number of adults & Number of adults between 16 and above & 2.798 & 1.810 & 2.779 & 1.778 \\
\hline Family assets & Total household asset values (ln) in Rupiah & 17.14 & 1.631 & 17.91 & 2.131 \\
\hline Bottom 25 percentile & $\begin{array}{l}\text { Asset values of households in the bottom } 25 \\
\text { percentile }\end{array}$ & 14.57 & 2.938 & $15.34^{2}$ & 2.573 \\
\hline $25-50$ percentile & $\begin{array}{l}\text { Asset values of households in the bottom } \\
25-50 \text { percentile }\end{array}$ & 16.92 & 0.300 & 17.64 & 0.338 \\
\hline 50-75 percentile & $\begin{array}{l}\text { Asset values of households in the top 25-50 } \\
\text { percentile }\end{array}$ & 17.86 & 0.257 & 18.67 & 0.280 \\
\hline Top 25 percentile & $\begin{array}{l}\text { Asset values of households in the top } 25 \\
\text { percentile }\end{array}$ & 19.19 & 0.689 & $19.98^{3}$ & 0.612 \\
\hline Family income & Annual family income (ln) in Rupiah & 14.81 & 4.664 & 18.71 & 9.738 \\
\hline Disasters & $\begin{array}{l}\text { Number of natural disasters experienced by } \\
\text { households }\end{array}$ & 0.114 & 1.466 & 0.505 & 2.667 \\
\hline
\end{tabular}


Table 1 (continued)

\begin{tabular}{|c|c|c|c|c|c|}
\hline \multirow{2}{*}{$\begin{array}{l}\text { Abbreviation } \\
\text { Dependent variables }\end{array}$} & & \multicolumn{2}{|l|}{2007} & \multicolumn{2}{|l|}{2014} \\
\hline & & Mean & SD & Mean & SD \\
\hline Economic shocks & $\begin{array}{l}1 \text { if experienced any shocks to household } \\
\text { economy }\end{array}$ & & & 0.045 & 0.207 \\
\hline Chronic illness (father) & Father's duration of chronic conditions & & & 0.172 & 1.581 \\
\hline Patients only & Fathers suffering from chronic conditions & & & 5.899 & 7.232 \\
\hline Chronic illness (mother) & Mother's duration of chronic conditions & & & 0.128 & 1.291 \\
\hline Patients only & Mothers suffering from chronic conditions & & & 4.638 & 6.302 \\
\hline ADL index (father) & $0=\min , 1=\max$ & 0.991 & 0.103 & 0.975 & 0.084 \\
\hline ADL index (mother) & $0=\min , 1=\max$ & 0.990 & 0.095 & 0.983 & 0.078 \\
\hline \multicolumn{6}{|l|}{ Village } \\
\hline Urban & 1 if urban area & & & 0.593 & 0.491 \\
\hline
\end{tabular}

Source IFLS $(2007,2014)$

1. 4 =tertiary education, $3=$ high school, $2=$ middle school, $1=$ elementary school, 2 . Approximately 350 USD, 3. Approximately 33,000 USD

$$
A^{h}\left(S W_{r}^{h}, S W_{c}^{h}\right)=S W_{r}^{h}-S W_{c}^{h}
$$

The aspirations gap variable is constructed based on 2007 and 2014 waves of surveys, which asked the respondents their current level of step and their expected level of step in 5 years later on an imaginary six-step ladder. The poorest people stand on the bottom while the richest people stand on the highest step. According to the data used in this paper, the mean level of current subjective wellbeing reported by household heads is roughly around 3 out of the maximum value of 6 in 2007, while the level is lowered slightly in 2014. Furthermore, the mean of the aspirations gap is slightly lower than 0.7 and appears to increase as the relative family income increases. ${ }^{9}$ In particular, household heads in the bottom $10 \%$ of household assets show a higher aspirations gap than richest $10 \%$ of household heads in 2007 (0.590 vs. 0.500). The next poorest group (10-25\%) also shows a slightly lower level of the aspirations gap, but it is still higher than that of the richest group. Those in the middle appear to have the highest level of the aspirations gap in our sample households (Fig. 1). The results are quite similar in the case of spouses (Fig. 2). Interestingly, the aspirations gap becomes much larger in the poorest group in 2014 while the richest group shows a little change, resulting in a much greater difference between these two groups. Overall, the increase in the aspirations gap appears to be inversely proportional to the wealth level between 2007 and 2014.

\subsection{Schooling of Children}

The dependent variable $\left(S_{i h}\right)$ in the estimation model was constructed by computing the difference between the schooling years $\left(S_{i h}^{y}\right)$ of each child (i) in each household (h) and the mean completed schooling years of his or her age cohort $\left(\bar{S}_{i h}\right)$ in 2007 and 2014 as follows.

\footnotetext{
9 The relative family income was computed based on the mean family income of each community. In particular, it was estimated as the ratio of family income relative to mean family income of the community.
} 


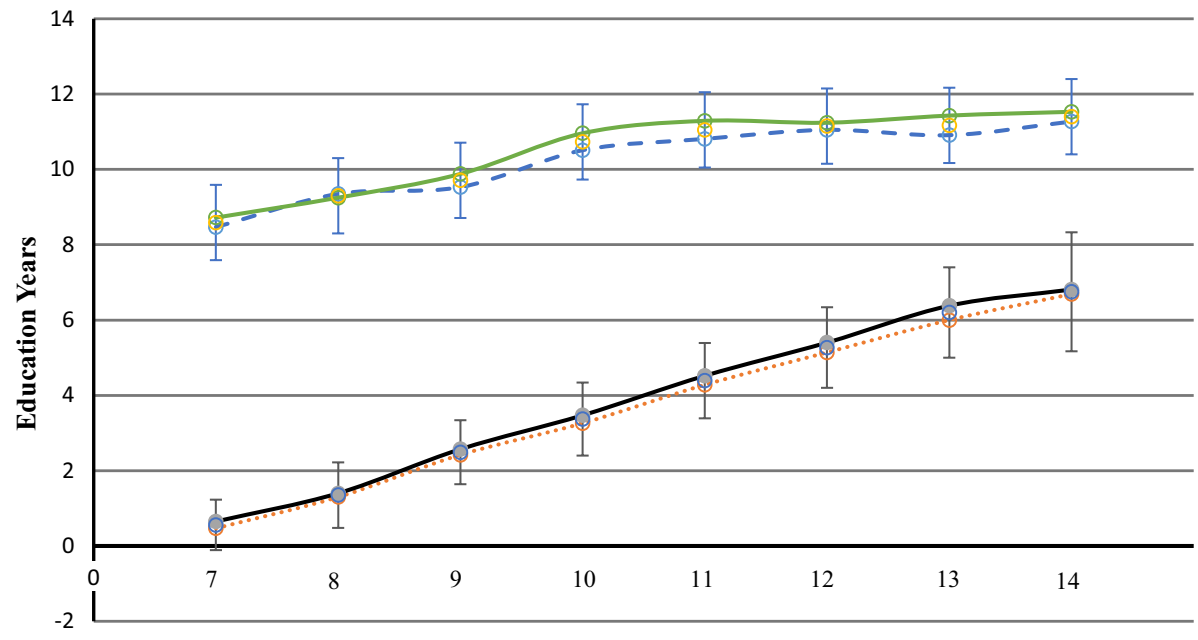

Age in 2007

$\cdots \odot \cdots$ girl $2007 \quad$ — boy $2007 \quad-\ominus-$ girl $2014 \quad$ — boy 2014

Fig. 4 Education years by age cohort

$$
S_{i h}=S_{i h}^{y}-\bar{S}_{i h}^{y},
$$

This variable of relative education levels is more advantageous than absolute education levels in that it can control for the heterogeneous parental effects on children of different ages in our estimation models. For instance, older children's schooling decisions may be less affected by their parents, and decisions on their human capital investment may be more sensitive to parental age and health conditions due to their higher earnings potential and the opportunity costs (Shavit and Blossfeld, 1993). Furthermore, the first-differenced dependent variable controls for some child-specific time-invariant characteristics.

Some may cast doubt on the validity of our relative schooling variables as a proxy for parental educational investment. We use educational attainment of children as an output of parental educational investments. This is consistent with our research goal to understand the linkage between socioeconomic status of family and educational outcomes of children. Expenditures on school related expenses may be used, but we believe that the variable measuring relative education years is a better proxy for educational investment for two reasons. First. the former is a flow variable while the latter is a stock variable in our data, and hence the expenditure variable is more likely to be affected by the time of the measurement. Second, we believe that it is the opportunity cost of schooling that matters more in children's human capital investment rather than the direct cost of schooling in Indonesia, where education is offered free of cost up until grade nine. Children may start working at the age of 13 and some children even work at a younger age for domestic work. Thus, the opportunity cost of schooling may be quite significant for the poor. For this reason, we use the schooling years as a proxy for the educational investment. The variable itself is also a key development indicator used in the human development index (HDI).

Figure 4 shows that boys on average get a higher level of schooling than girls at almost all age cohort. It also shows that children get a higher level of schooling at all age cohorts in 2014 compared to 2007. On the other hand, the data show that children of poorer 
families achieve relatively fewer schooling years than richer ones between 2007 and 2014, and the gap appears to be quite substantial (Fig. 3). In particular, children in households with top $10 \%$ of total household asset values achieve 1.76 more years of schooling between 2007 and 2014 than those in households with bottom 10\% of asset values, and the gap is even greater for girls. ${ }^{10}$ This implies that intergenerational transmission of poverty may occur via a channel of inadequate aspirations as the poor tend to underinvest in children's human capital.

\section{Model Specification and Identification Strategy}

This study seeks to examine the effects of the aspirations gap of household heads on schooling of their children in Indonesia. To this end, we test two main null hypotheses: (1) The aspirations gap of a parent has no effect on schooling of children; and (2) The change in the aspirations gap of a parent has no effect on schooling of children. For the test of the first hypothesis, this paper uses the following regression model with village fixed effects and estimate the change in relative educational levels $(\Delta \mathrm{S})$ of child $i$ living in household $h$ in village $v$ between 2007 and 2014:

$$
\Delta S_{i h v}=\alpha_{0}+\alpha_{v}+\beta_{1} A_{h v}^{P}+\beta_{2} A_{h v}^{P 2}++\beta_{3} \Delta I_{i h v}^{\prime}+\beta_{4} \overline{I_{i h v}^{\prime}}+\beta_{5} \Delta H_{h v}^{\prime}+\beta_{6} \overline{H_{h v}^{\prime}}+\varepsilon_{i h v},
$$

where $A_{h v}^{P}$ measures the aspirations gap of parents, which is constructed by the difference between current subjective wellbeing as of 2007 and their aspired level of wellbeing five years later. A quadratic term $A_{h v}^{P 2}$ is included to test for the presence of an inverse U-shape. $I_{h}^{\prime}$ and $\bar{I}_{h}$ represent vectors of individual time-varying and time-invariant characteristics, which include the change in health status and other control variables such as the relative education level in 2007, age, gender, and a dummy for a first child. $H_{h}^{\prime}$ and $\bar{H}_{h}$ represent vectors of household time-varying and time-invariant characteristics, which include the educational level of parents, age of the household head, the value of household assets, ${ }^{11}$ and the change in numbers of children and adults in the households.

The first-differenced relative education level sweeps out some correlation from omitted unobserved individual characteristics that confound identifying the effect of parental aspirations on children's educational attainment. Nevertheless, there may be other unobservable confounding factors that affect the estimation of the aspirations effect at higher than individual levels. For instance, exposure to individuals with a higher educational level and economic status may matter in formation of educational aspirations for children (Chiapa et al., 2012; Janzen et al, 2017; Jensen, 2010, 2012; Nguyen, 2008). At the same time, such exposure may increase parents' aspirations for their own wellbeing by affecting their aspirational window (Ray, 2006). Furthermore, there may be some communities where education is devalued due to lower returns to human capital investment than other regions. People in some communities may believe that jobs in their local economy do not require

\footnotetext{
10 The relative educational levels show similar but somewhat lower variations with relative family income. The results are not reported in this paper.

11 Due to a potential endogeneity issue, this paper uses the total value of assets as of 2007. Also, the assets are used instead of household income to distinguish deep-rooted, persistent structural poverty from poverty that passes naturally with time due to economy wide growth processes. See Carter and Barrett for the reasoning (2006).
} 
academic skills while more competitive urban job markets are too far from their community to consider. The aspirational window of those people may thus be different from that of others living in or closer to urban areas, which in turn is likely to affect their investment in children's human capital. For these reasons, we control for community-fixed effects in the estimation of educational attainment of children. In particular, $\alpha_{v}$ controls for community-specific unobservables that confound identifying the effect of wellbeing aspirations of parents. In this paper, the community fixed effect is controlled at the level of kecamatan, which is equivalent to a subdistrict of regency or city. ${ }^{12}$ A value of $\beta_{1}$ significantly different from zero would reject the null hypothesis that the aspirations gap of a parent has no effect on schooling of children. Also, a significantly negative value of $\beta_{2}$ would prove the presence of an inverted $U$ relationship between the parental aspirations gap and schooling of children.

One concern with our estimation is that schooling of children may have a feedback impact on the aspirations gap of parents. For instance, parents may plan to send their children to work during or after their junior secondary or high school years if the household needs the additional income. ${ }^{13}$ Household heads in such a plan would anticipate higher household income, which in turn would raise their future reference level of wellbeing. The estimates of $\beta_{1}$ and $\beta_{2}$ would then be biased. To address this issue, we examine the differential effects of parental aspirations gap on schooling of younger children (6-12 years in 2007) and older ones (13 years and older in 2007). In the presence of such a feedback effect, educational attainment of children would be inversely associated with future reference points and the aspirations gap of their parents. Moreover, given the higher opportunity cost of schooling for older children, the coefficient on the parental aspirations gap is supposed to be negative and greater than that in the younger group. We present the results in the sensitivity analysis Sect. 5.3.

For the test of the second hypothesis, we use the following individual fixed effect model.

$$
S_{i h v t}=\alpha_{0}+\alpha_{i}+{ }_{t}+\beta_{1} A_{h v t}^{P}+\beta_{2} A_{h v t}^{P 2}+\beta_{3} I_{i h v t}^{\prime}+\beta_{4} H_{h v t}^{\prime}+\beta_{5} V_{v t}^{\prime}+\varepsilon_{i h v t},
$$

where $\alpha_{i}$ controls for child-specific unobservables. $I_{h}^{\prime}, H_{h}^{\prime}$, and $V_{v t}^{\prime}$ represent vectors of individual, household, and village time-varying characteristics, respectively. $A_{h v t}^{P}$ and $A_{h v t}^{P 2}$ are the aspirations gap of parents and the quadratic term, respectively. The model also controls for changes in local economy $V_{v t}^{\prime}$ by including variables measuring the mean wages of male and female workers as well as the mean income of each village in 2007 and 2014. In both models (3) and (4), importantly, we directly control for one major source of spurious correlation, shocks to household economies that may affect both schooling of children and aspirations by including a variable capturing natural disaster shocks measured at the household level. The 2007 and 2014 waves of the IFLS data allow one to deal with some of the endogeneity issues as they contain information on natural disasters that caused economic disruption over the past five years. The disasters include drought, flood, earthquakes, fire, and Tsunami. Furthermore, the survey includes information about other idiosyncratic household income shocks such as failed harvests, job losses, and business failures. We also include the idiosyncratic income shock variable in the estimation models. The coefficients $\beta_{1}$ and $\beta_{2}$ present estimates of the treatment effects of parental aspirations gap on schooling

\footnotetext{
12 We decided to control at the Kecamatan level because school quality is likely to affect educational outcome of children. School quality not only varies between cities but also within cities.

13 Under Indonesian law, the minimum working age is 15 , but light work can be done as of age 13 .
} 
of children. A value of $\beta_{1}$ significantly different from zero would reject the null hypothesis that the change in the aspirations gap of a parent has no effect on schooling of children. Similar to the previous model, an inverted U relationship would be identified by a significantly negative value of $\beta_{2}$.

\section{Estimation Results}

\subsection{Effects of the Aspirations Gap on Schooling of Children}

Table 2 presents estimation results of models that estimate the aspirations gap effects of the household heads and the spouses on schooling of their children. The first three models estimate the effects using education years as the dependent variable while the next three models estimate using relative education years as the dependent variable. In the discussions of our results, we focus on the relative education years due to the advantage over the absolute education years as explained in Sect. 3.2. Assuming education decisions are primarily made by household heads, we also focus on the aspirations gap of household heads. In all models, the results show that the head's aspirations gap positively affects schooling of children. In particular, according to the first difference fixed-effect model (FE 4) using the relative education years, our preferred model, the mean aspirations gap (0.678) of household heads in 2007 is associated with an approximately 2 months longer schooling years than the same age cohort of children between 2007 and $2014(P<0.01) \cdot{ }^{14}$ Interestingly, the squared term of the aspirations gap variable shows negative coefficients in both models, indicating an inversely U-shaped relationship between the aspirations gap and schooling of children. This implies that, an excessive aspirations gap, ceteris paribus, leads to underinvestment in children's human capital. The spouse's aspirations gap is also positively associated with the schooling of children. However, the coefficients on the aspirations gap variables are much smaller. Figure 5 presents the nonlinear effects of parental aspirations gap on relative schooling of children. Our calculation shows that the maximum effect occurs at the gap of 1.06 for household heads. After the threshold value, the effect of the aspirations gap gradually diminishes.

Other control variables commonly used in the literature also have expected signs. Children achieve relatively longer schooling years between 2007 and 2014, compared to their age same cohort, when their parents are more educated and wealthier. Consistent with general findings in the literature, boys appear to achieve longer schooling years than girls in Indonesia, but the first child in family does not appear to achieve longer schooling years than other siblings. Also, consistent with the quantity-quality model of children (Becker, 1960; Becker \& Lewis, 1973; Becker \& Tomes, 1976), the results show a negative correlation between the number of children and schooling of children. On the other hand, there is no evidence that natural disasters, one major source of spurious correlation, affect schooling of children. Idiosyncratic shocks to household economies do not appear to affect the schooling of children, either. Furthermore, regression results with the two variables show

\footnotetext{
14 The model is preferred because it uses the relative education years as the dependent variable while controlling for village fixed effects and shocks to household economies, one major source of spurious correlation.
} 
Table 2 Effects of aspirations gap on schooling of children

\begin{tabular}{|c|c|c|c|c|c|c|}
\hline & \multicolumn{3}{|c|}{$\Delta$ Absolute education years } & \multicolumn{3}{|c|}{$\Delta$ Relative education years } \\
\hline & OLS1 & FE1 & FE2 & OLS2 & FE3 & FE4 \\
\hline $\begin{array}{l}\text { Education } \\
\text { (head) }\end{array}$ & $\begin{array}{l}0.390 * * * \\
(0.057)\end{array}$ & $\begin{array}{l}0.334 * * * \\
(0.070)\end{array}$ & $\begin{array}{l}0.334 * * * \\
(0.071)\end{array}$ & $\begin{array}{l}0.392 * * * \\
(0.057)\end{array}$ & $\begin{array}{l}0.320 * * * \\
(0.073)\end{array}$ & $\begin{array}{l}0.321 * * * \\
(0.075)\end{array}$ \\
\hline $\begin{array}{l}\text { Education } \\
\text { (spouse) }\end{array}$ & $\begin{array}{l}0.182 * * * \\
(0.056)\end{array}$ & $\begin{array}{l}0.203 * * * \\
(0.075)\end{array}$ & $\begin{array}{l}0.200 * * * \\
(0.076)\end{array}$ & $\begin{array}{l}0.181 * * * \\
(0.056)\end{array}$ & $\begin{array}{l}0.207 * * * \\
(0.077)\end{array}$ & $\begin{array}{l}0.203 * * * \\
(0.077)\end{array}$ \\
\hline $\begin{array}{l}\text { Aspirations gap } \\
\text { (head) } 2007\end{array}$ & $\begin{array}{l}0.186 * * \\
(0.078)\end{array}$ & $\begin{array}{l}0.384 * * * \\
(0.101)\end{array}$ & $\begin{array}{l}0.389 * * * \\
(0.101)\end{array}$ & $\begin{array}{l}0.235 * * * \\
(0.079)\end{array}$ & $\begin{array}{l}0.461 * * * \\
(0.103)\end{array}$ & $\begin{array}{l}0.465^{* * *} \\
(0.102)\end{array}$ \\
\hline $\begin{array}{l}\text { Aspirations gap^ } 2 \\
\text { (head) } 2007\end{array}$ & $\begin{array}{l}-0.105^{* *} \\
(0.048)\end{array}$ & $\begin{array}{l}-0.188^{* * *} \\
(0.062)\end{array}$ & $\begin{array}{l}-0.189^{* * *} \\
(0.062)\end{array}$ & $\begin{array}{l}-0.126^{* * *} \\
(0.047)\end{array}$ & $\begin{array}{l}-0.218^{* * *} \\
(0.060)\end{array}$ & $\begin{array}{l}-0.219 * * * \\
(0.061)\end{array}$ \\
\hline $\begin{array}{l}\text { Aspirations gap } \\
\text { (spouse) } 2007\end{array}$ & $\begin{array}{l}0.124 \\
(0.093)\end{array}$ & $\begin{array}{l}0.275 * * \\
(0.123)\end{array}$ & $\begin{array}{l}0.277 * * \\
(0.124)\end{array}$ & $\begin{array}{l}0.101 \\
(0.097)\end{array}$ & $\begin{array}{l}0.279 * * \\
(0.122)\end{array}$ & $\begin{array}{l}0.281 * * \\
(0.123)\end{array}$ \\
\hline $\begin{array}{l}\text { Aspirations gap }{ }^{\wedge} 2 \\
\text { (spouse) } 2007\end{array}$ & $\begin{array}{l}-0.082 * * \\
(0.034)\end{array}$ & $\begin{array}{l}-0.144 * * * \\
(0.043)\end{array}$ & $\begin{array}{l}-0.145^{* * *} \\
(0.043)\end{array}$ & $\begin{array}{l}-0.073^{*} \\
(0.037)\end{array}$ & $\begin{array}{l}-0.146^{* * * *} \\
(0.044)\end{array}$ & $\begin{array}{l}-0.148 * * * \\
(0.045)\end{array}$ \\
\hline Age & $\begin{array}{l}-0.409 * * * \\
(0.030)\end{array}$ & $\begin{array}{l}-0.422 * * * \\
(0.035)\end{array}$ & $\begin{array}{l}-0.422 * * * \\
(0.035)\end{array}$ & $\begin{array}{l}0.005 \\
(0.030)\end{array}$ & $\begin{array}{l}-0.005 \\
(0.035)\end{array}$ & $\begin{array}{l}-0.005 \\
(0.035)\end{array}$ \\
\hline Head age & $\begin{array}{l}0.007 \\
(0.006)\end{array}$ & $\begin{array}{l}0.009 \\
(0.007)\end{array}$ & $\begin{array}{l}0.009 \\
(0.007)\end{array}$ & $\begin{array}{l}0.007 \\
(0.006)\end{array}$ & $\begin{array}{l}0.010 \\
(0.007)\end{array}$ & $\begin{array}{l}0.009 \\
(0.007)\end{array}$ \\
\hline $\begin{array}{l}\text { Relative education } \\
\text { (2007) }\end{array}$ & $\begin{array}{l}-0.038 \\
(0.079)\end{array}$ & $\begin{array}{l}-0.051 \\
(0.091)\end{array}$ & $\begin{array}{l}-0.049 \\
(0.091)\end{array}$ & $\begin{array}{l}-0.121 \\
(0.079)\end{array}$ & $\begin{array}{l}-0.136 \\
(0.092)\end{array}$ & $\begin{array}{l}-0.135 \\
(0.092)\end{array}$ \\
\hline First child & $\begin{array}{l}0.014 \\
(0.102)\end{array}$ & $\begin{array}{l}-0.028 \\
(0.124)\end{array}$ & $\begin{array}{l}-0.030 \\
(0.124)\end{array}$ & $\begin{array}{l}0.038 \\
(0.103)\end{array}$ & $\begin{array}{l}-0.029 \\
(0.125)\end{array}$ & $\begin{array}{l}-0.031 \\
(0.125)\end{array}$ \\
\hline Gender $(1=$ boy $)$ & $\begin{array}{l}0.143 * * * \\
(0.052)\end{array}$ & $\begin{array}{l}0.127 * * \\
(0.060)\end{array}$ & $\begin{array}{l}0.128 * * \\
(0.060)\end{array}$ & $\begin{array}{l}0.155^{* * * *} \\
(0.052)\end{array}$ & $\begin{array}{l}0.124 * * \\
(0.060)\end{array}$ & $\begin{array}{l}0.124 * * \\
(0.060)\end{array}$ \\
\hline$\Delta$ child health & $\begin{array}{l}-0.034 \\
(0.062)\end{array}$ & $\begin{array}{l}-0.041 \\
(0.080)\end{array}$ & $\begin{array}{l}-0.037 \\
(0.081)\end{array}$ & $\begin{array}{l}-0.049 \\
(0.063)\end{array}$ & $\begin{array}{l}-0.052 \\
(0.081)\end{array}$ & $\begin{array}{l}-0.048 \\
(0.082)\end{array}$ \\
\hline Asset (ln) 2007 & $\begin{array}{l}0.127 * * \\
(0.051)\end{array}$ & $\begin{array}{l}0.139 * \\
(0.076)\end{array}$ & $\begin{array}{l}0.141^{*} \\
(0.073)\end{array}$ & $\begin{array}{l}0.138 * * \\
(0.057)\end{array}$ & $\begin{array}{l}0.160 * \\
(0.086)\end{array}$ & $\begin{array}{l}0.163 * \\
(0.083)\end{array}$ \\
\hline$\Delta \#$ of children & $\begin{array}{l}-0.159 * * * \\
(0.049)\end{array}$ & $\begin{array}{l}-0.195^{* * *} \\
(0.058)\end{array}$ & $\begin{array}{l}-0.195^{* * *} \\
(0.057)\end{array}$ & $\begin{array}{l}-0.166^{* * *} \\
(0.049)\end{array}$ & $\begin{array}{l}-0.207 * * * \\
(0.059)\end{array}$ & $\begin{array}{l}-0.207 * * * \\
(0.059)\end{array}$ \\
\hline$\Delta \#$ of adults & $\begin{array}{l}-0.052 \\
(0.039)\end{array}$ & $\begin{array}{l}-0.074 \\
(0.046)\end{array}$ & $\begin{array}{l}-0.076^{*} \\
(0.046)\end{array}$ & $\begin{array}{l}-0.056 \\
(0.039)\end{array}$ & $\begin{array}{l}-0.070 \\
(0.047)\end{array}$ & $\begin{array}{l}-0.072 \\
(0.047)\end{array}$ \\
\hline$\Delta \#$ of natural disasters & $\begin{array}{l}-0.012 \\
(0.016)\end{array}$ & & $\begin{array}{l}-0.011 \\
(0.019)\end{array}$ & $\begin{array}{l}-0.010 \\
(0.016)\end{array}$ & & $\begin{array}{l}-0.008 \\
(0.018)\end{array}$ \\
\hline Economic shocks & $\begin{array}{l}-0.115 \\
(0.314)\end{array}$ & & $\begin{array}{l}0.107 \\
(0.391)\end{array}$ & $\begin{array}{l}-0.125 \\
(0.326)\end{array}$ & & $\begin{array}{l}0.116 \\
(0.413)\end{array}$ \\
\hline Urban residency & $\begin{array}{l}-0.011 \\
(0.114)\end{array}$ & $\begin{array}{l}0.257 \\
(0.418)\end{array}$ & $\begin{array}{l}0.255 \\
(0.419)\end{array}$ & $\begin{array}{l}-0.003 \\
(0.116)\end{array}$ & $\begin{array}{l}0.262 \\
(0.422)\end{array}$ & $\begin{array}{l}0.261 \\
(0.423)\end{array}$ \\
\hline Obs & 1346 & 1346 & 1346 & 1346 & 1346 & 1346 \\
\hline R-squared & 0.275 & 0.524 & 0.524 & 0.142 & 0.430 & 0.430 \\
\hline Village FE & No & Yes & Yes & No & Yes & Yes \\
\hline
\end{tabular}

$* p<0.05,{ }^{* *} p<0.01, * * * p<0.001$

Heteroskedasticity-robust standard errors are in parenthesis. All standard errors were adjusted for within cluster dependence at the household level 


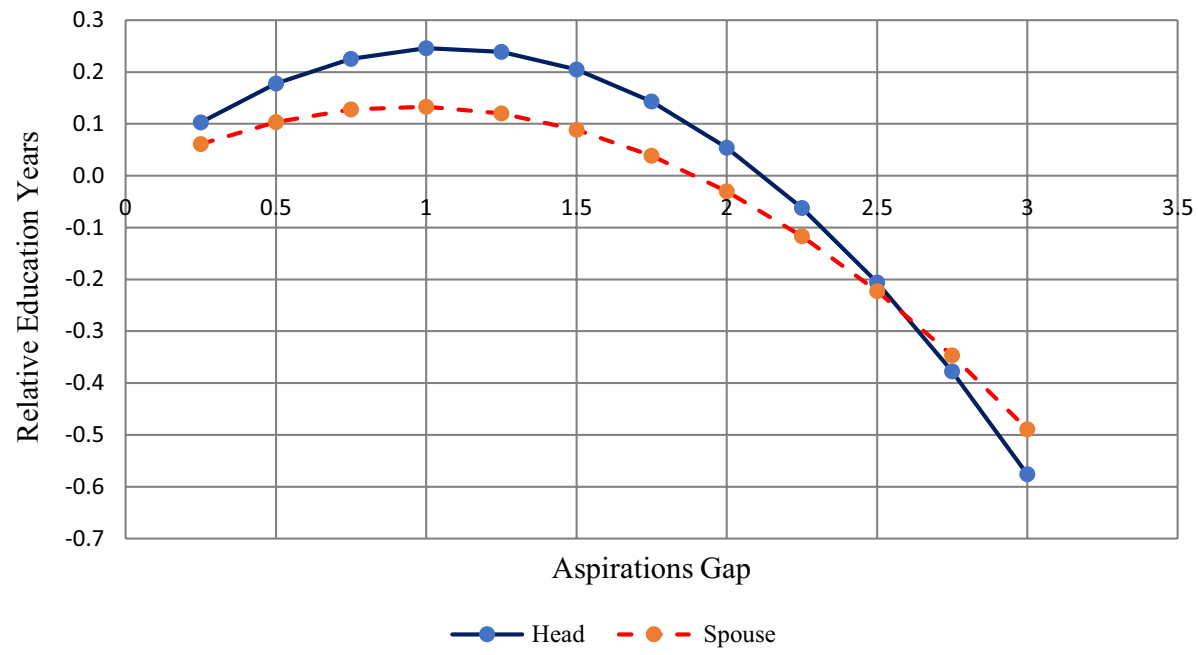

Fig. 5 Effects of the parental aspirations gap on relative schooling of children

that the magnitudes of the coefficients on the aspirations gap variables remain almost the same. ${ }^{15}$

\subsection{Differential Effects of the Aspirations Gap on Schooling of Boys and Girls}

In this section, we delve into a possible gender bias in human capital investment in Indonesia. Without any gender bias, the effect of aspirations gap of parents, ceteris paribus, should be the same on the schooling of boys and girls. The first four models in Table 3 show regression results using only the sample of boys while the next four models show results from the sample of girls. According to the results, the aspirations gap of the household head affects schooling of boys only, while there is no evidence that girls are affected by the parental aspirations gap. In particular, the result from the fixed-effects model (Boys 4) shows that the mean aspirations gap of household heads, ceteris paribus, is associated with approximately 3 months longer schooling years than the same age cohort of boys between 2007 and 2014. Again, the negative coefficient on the squared term of the aspirations gap variable implies an inversely U-shaped relationship between the aspirations gap and schooling of boys. The nonlinear relationship is also presented in Fig. 6, which also shows gender bias in schooling. It shows that relative education years of boys are positively associated with the aspirations gap of household heads up to the gap of 1.5, and diminish after the point. In contrast, relative of education years of girls do not appear to be influenced by the aspirations gap of heads.

Mother's aspirations gap seems to affect the schooling of girls, but the effects are only weakly significant at the $p<0.1$ level in the model without the natural disasters and economic shocks variables. Interestingly, the coefficients on the change in number of children are larger and more significant in the models using only the sample of girls, while there is

\footnotetext{
15 This may be due to the village fixed effects included in the estimation model. The two variables were measured at the household level, so the effects can be estimated in the village fixed effect model.
} 


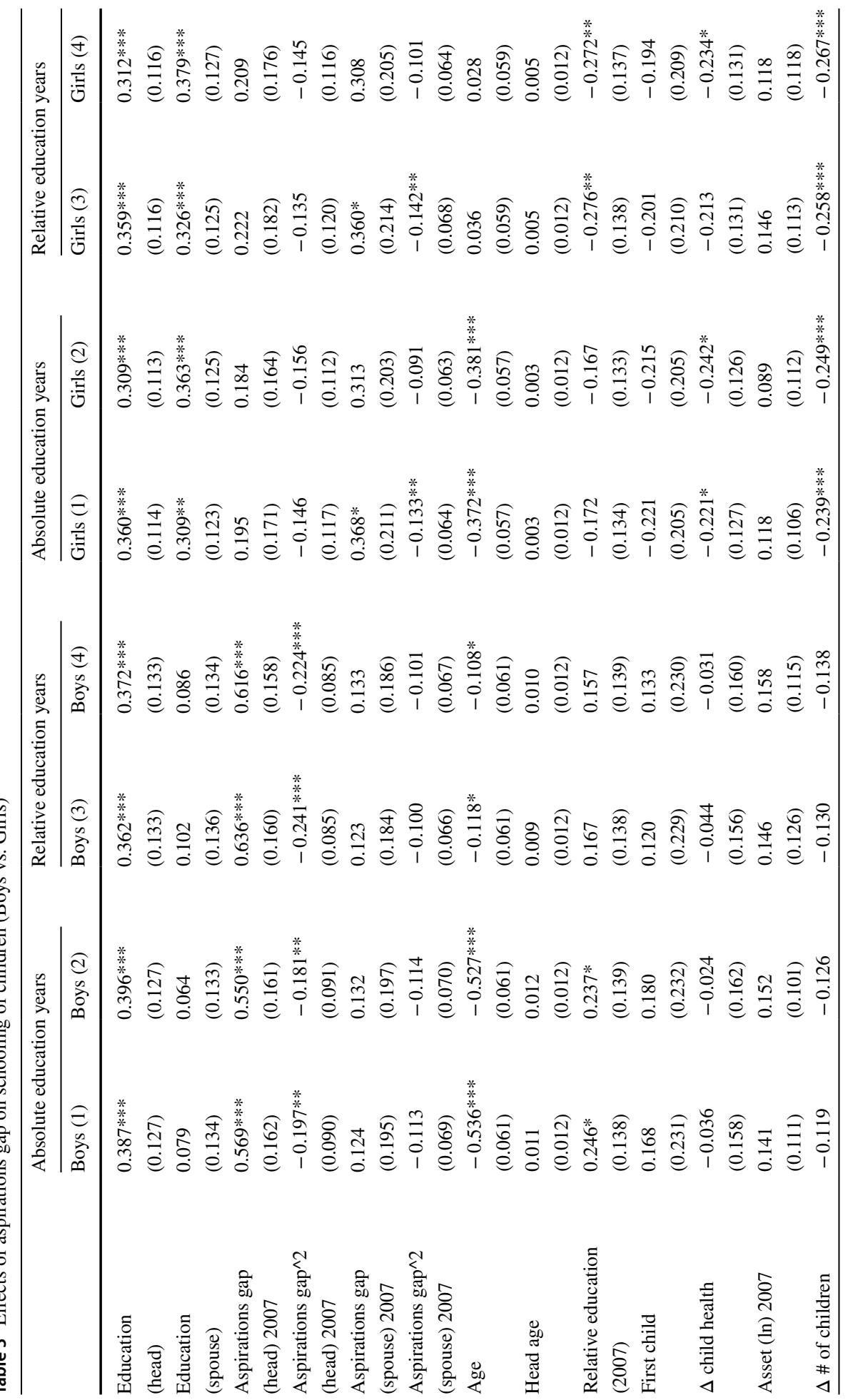




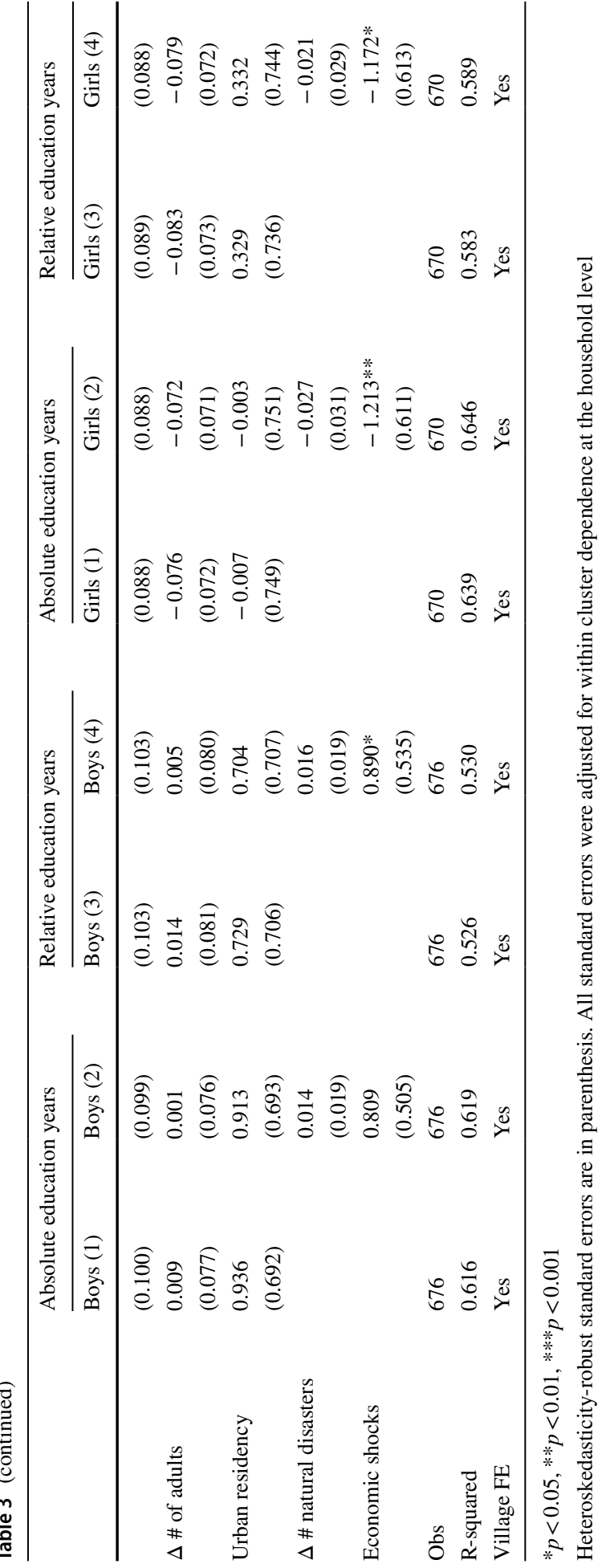




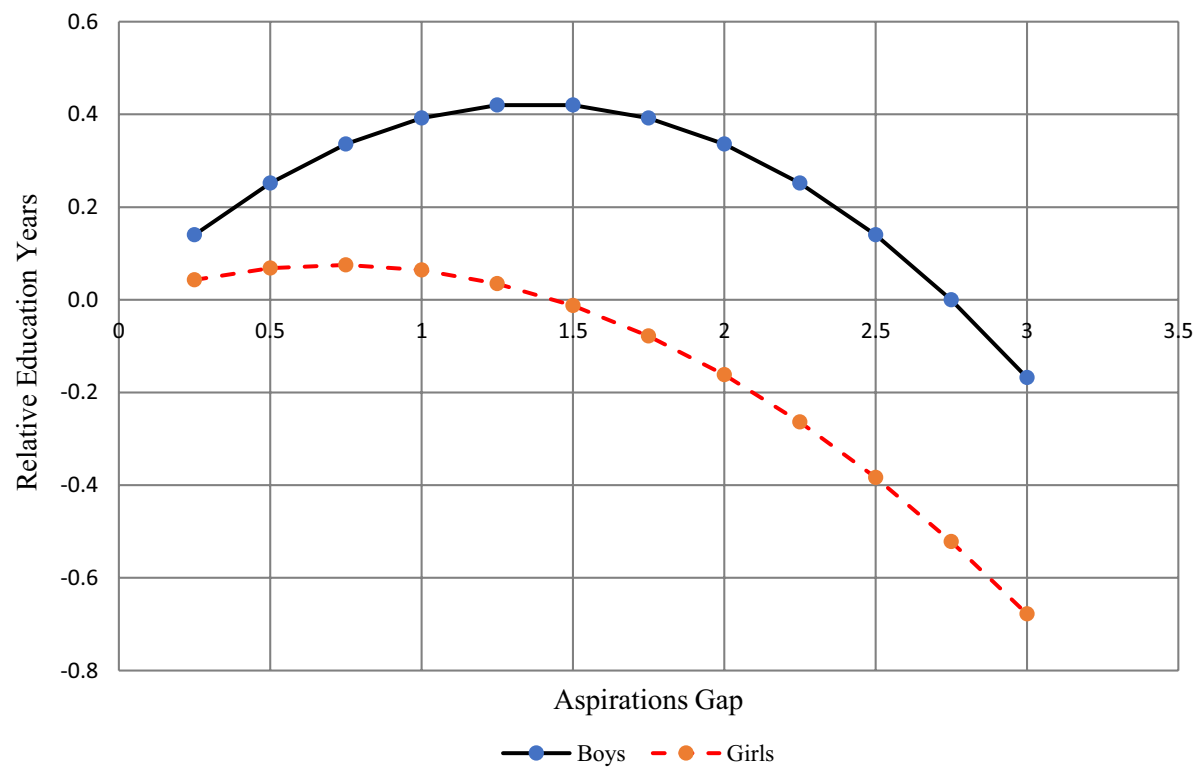

Fig. 6 Effects of the head's aspirations gap on relative schooling of boys and girls

no evidence that schooling of boys is affected by the number of children. It indicates that the trade-off between child quantity and quality is more likely to be an issue in the schooling of girls rather than boys in Indonesia.

\subsection{Sensitivity Analysis}

An alternative interpretation of the previous results is that the aspirations gap in this study may simply reflect the anticipated income changes of household heads. A higher aspirations gap in this case would not necessarily mean a higher hope or ambition of achieving a higher level of economic wellbeing. This view, however, is problematic for two reasons. First, households are unlikely to have a clear anticipation about their economic situation in five years later especially in Indonesia, where over $60 \%$ of the labor force is working in an informal sector. Second, the inversely U-shaped relation between the aspirations gap and children's educational attainment is hard to explain if the aspiration gap simply reflects the anticipated income changes of the household. It is hard to rationalize the nonlinear relationship between an anticipated income growth and educational attainment of children between 2000 and 2007.

One may still argue that changes in child schooling may feedback into family income as children enter the labor market leaving their school, anticipation of which may be captured by a higher aspirations gap. In this case, the higher aspirations gap would be associated with lower relative educational attainment of children. However, according to our additional regressions with disaggregated data, the coefficients on head's aspiration gap are positive and almost twice larger for boys of junior secondary school age (13-15 years old) compared to younger ones in 2007 in all models (Table 4). The results imply that older boys are more likely to stay in school when their fathers' future reference points are higher 
Table 4 Effects of aspirations gap on schooling of children (6-12 years vs. 13 years +)

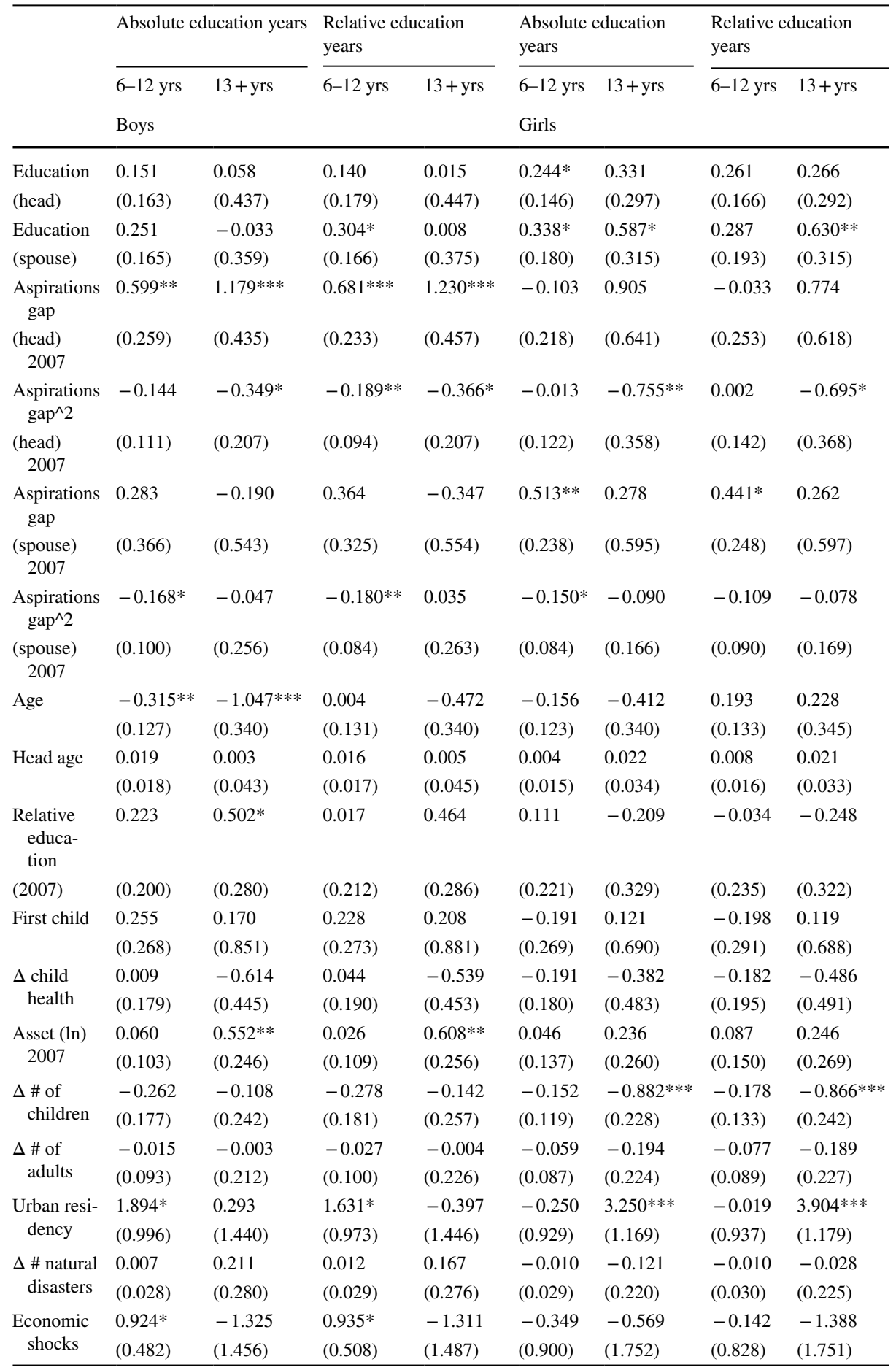


Table 4 (continued)

\begin{tabular}{|c|c|c|c|c|c|c|c|c|}
\hline & \multicolumn{2}{|c|}{ Absolute education years } & \multicolumn{2}{|c|}{$\begin{array}{l}\text { Relative education } \\
\text { years }\end{array}$} & \multicolumn{2}{|c|}{$\begin{array}{l}\text { Absolute education } \\
\text { years }\end{array}$} & \multicolumn{2}{|c|}{$\begin{array}{l}\text { Relative education } \\
\text { years }\end{array}$} \\
\hline & $6-12$ yrs & $13+y r s$ & $6-12 \mathrm{yrs}$ & $13+y r s$ & $6-12$ yrs & $13+y r s$ & $6-12 \mathrm{yrs}$ & $13+y r s$ \\
\hline & Boys & & & & Girls & & & \\
\hline Obs & 408 & 268 & 408 & 268 & 404 & 266 & 404 & 266 \\
\hline R-squared & 0.664 & 0.820 & 0.640 & 0.797 & 0.686 & 0.874 & 0.645 & 0.874 \\
\hline Village FE & Yes & Yes & Yes & Yes & Yes & Yes & Yes & Yes \\
\hline
\end{tabular}

$* p<0.05, * * p<0.01, * * * p<0.001$

Heteroskedasticity-robust standard errors are in parenthesis. All standard errors were adjusted for within cluster dependence at the household level

than their current wellbeing. Given the higher opportunity cost of older boys' schooling, the results are not explained by the alternative interpretation. If the alternative interpretation were true, the older boys whose fathers have a higher aspirations gap or higher anticipated family income would have lower relative schooling years, compared to other boys of their same age cohort.

We also ran additional regressions by replacing the asset variable measured in 2007 with the change in yearly family income variable in the estimation models. The change in family income is supposed to capture the effects of expected income change. The results are reported in Table 5. All the models in the table also control for religious diversity as children of minority religions may experience difficulties enrolling in school as many Indonesians face religious discrimination (Colbran, 2010). Overall, the results are quite similar to the previous estimation results with the additional religion variables, whether we use the change in absolute family income or relative family income in the models (Table 5). ${ }^{16}$

Another concern with the previous estimation is that health shocks to prime age adults in households may affect the aspirations gap of household heads, which in turn may affect their investment decisions on their children's human capital. Fortunately, IFLS data provide detailed information about household members' health status, morbidity experience, and physical health assessments conducted by health workers with special training in taking such measurements. In the 2014 wave of the IFLS, respondents were asked whether they had been diagnosed with a set of chronic conditions such as hypertension, tuberculosis, cancer, depression, or heart disease. If they had been diagnosed with some chronic illnesses, they were further asked when they were first diagnosed and whether their physical activities were limited by those symptoms. According to the sample used in this study, approximately 14 percent of fathers and 10 percent of mothers reported chronic conditions that limit the amount of paid work they could do to some extent. Table 6 present results from regressions using additional health measures for chronic conditions. For each gender, model (1) and model (3) The coefficients on the aspirations gap variable, again, remain quite close to the previous ones while they are slightly higher with the new variables in all

\footnotetext{
16 We also ran an additional regression run to check if the aspirations gap simply reflects the anticipated income changes, but no evidence of association between two variables was found from a model that regresses the change in family income on the aspirations gap and other control variables. The result is not reported in this paper, but available upon request.
} 


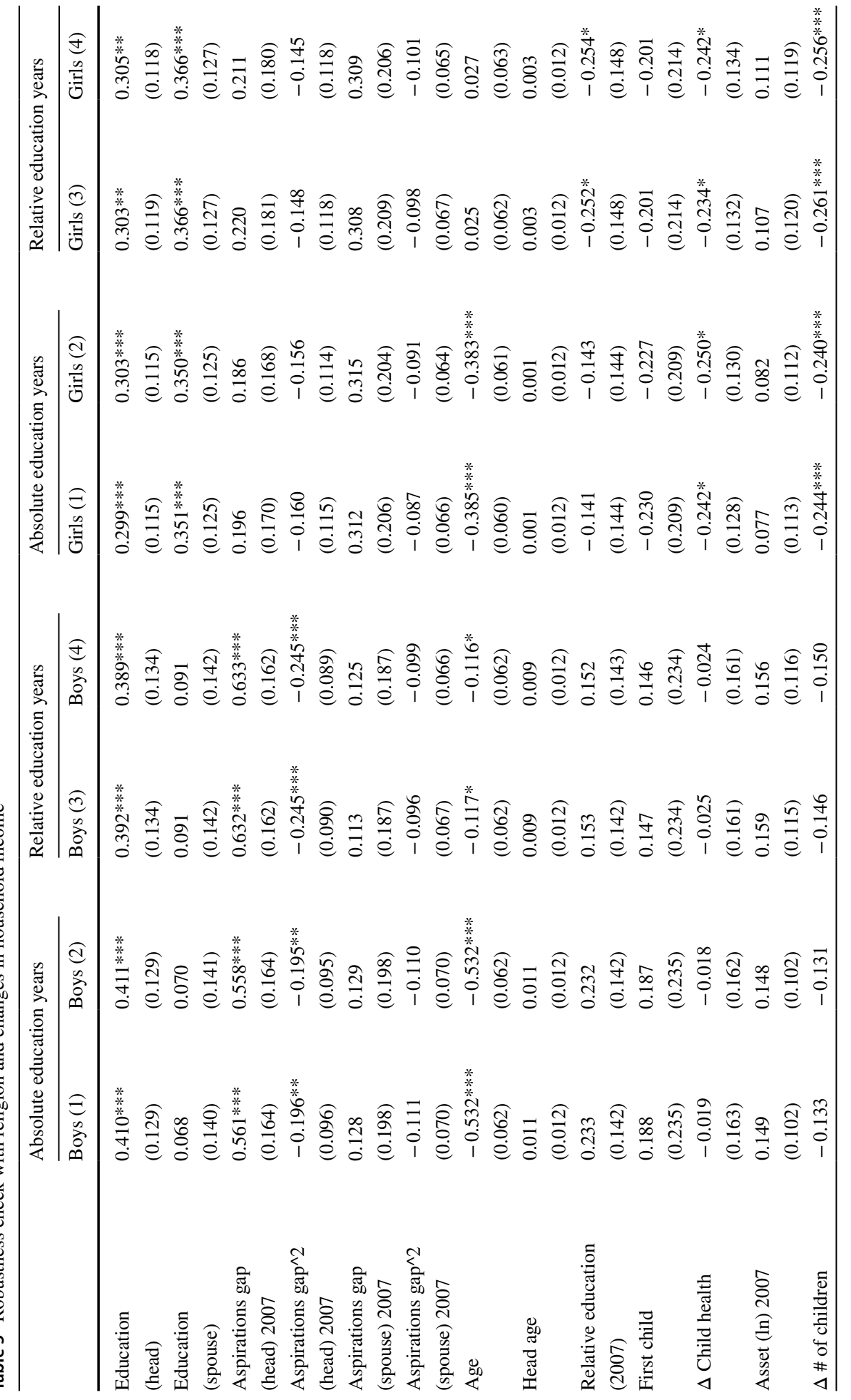




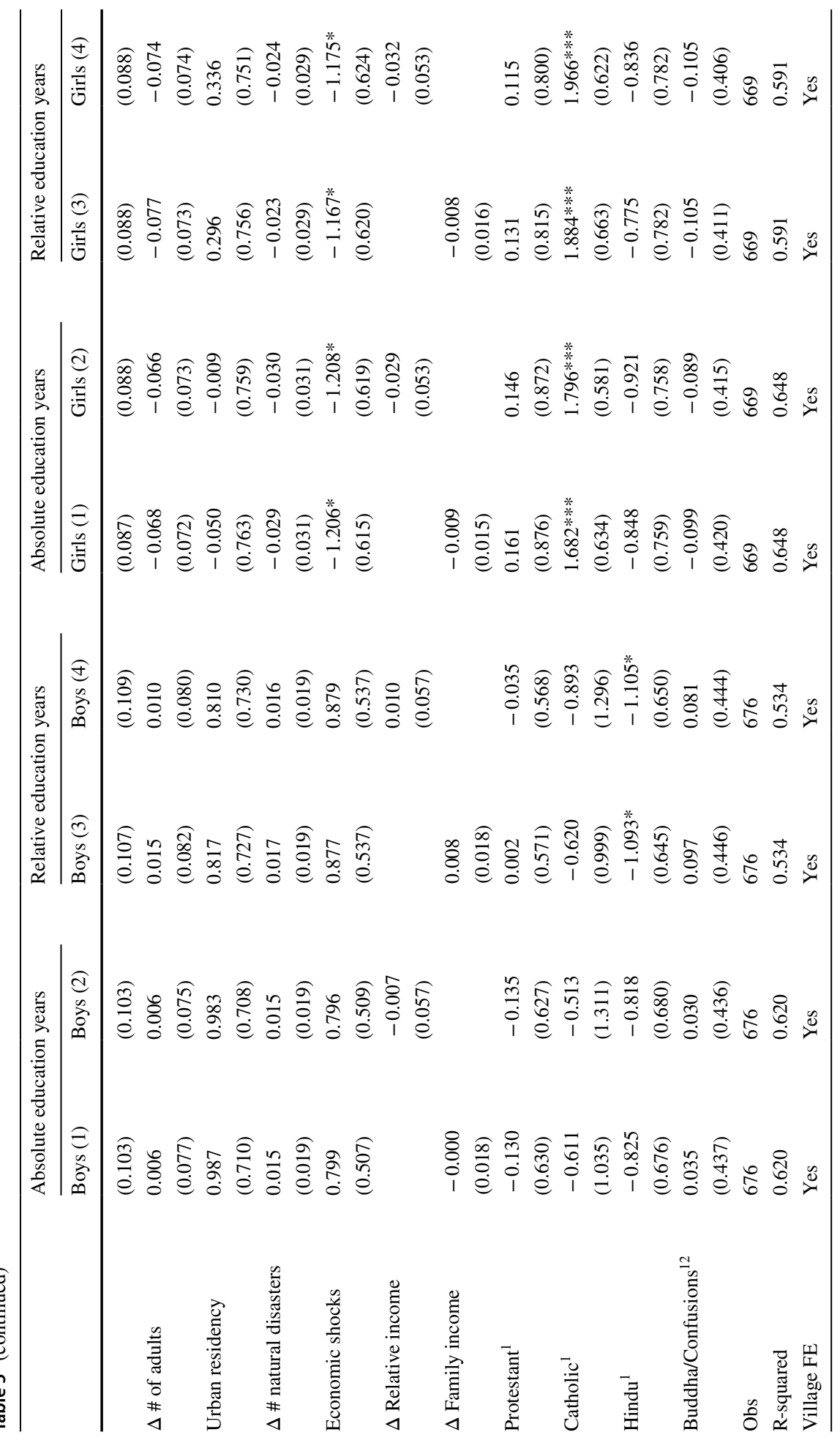




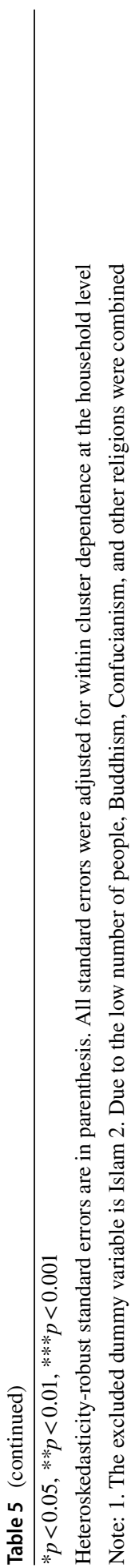

Springer 


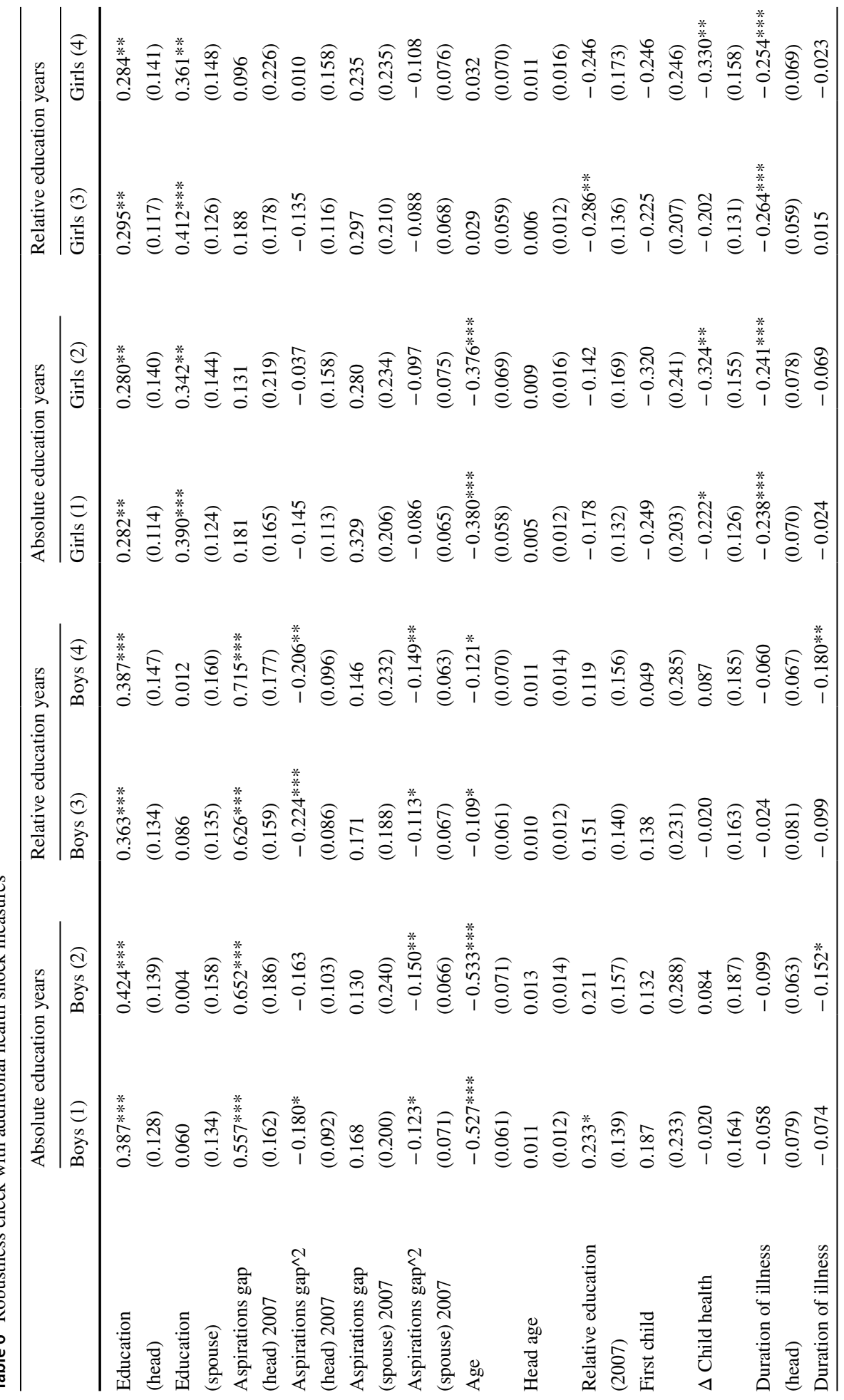




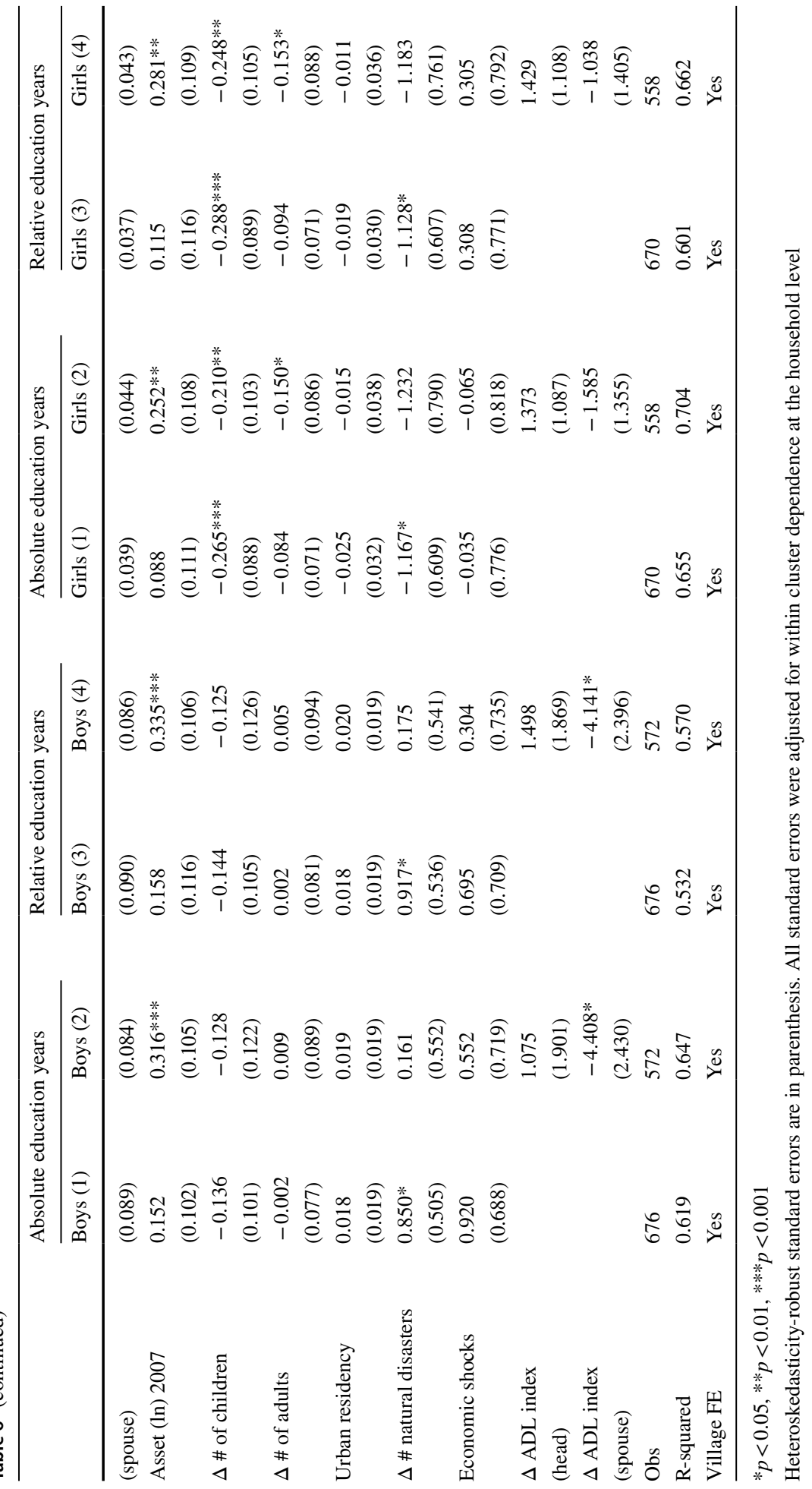


models. Interestingly, the duration of illness appears to affect only the schooling of girls and the effects are significant at the $P<0.01$ level in all models.

One concern related to this health measure is that it is not completely immune to a bias that may arise when using only a single self-reported measure of health status. The chronic conditions were based on diagnosis results by health practitioners, but the subjective severity of symptoms may differ by age, gender, education, and other personal characteristics. For this reason, models (2) and (4) in each gender in Table 6 use measures of individuals' physical abilities to perform activities of daily living (ADLs) such as bathing, feeding, clothing, rising and standing from sitting, and going to the toilet. Responses to ADL questions were coded to three levels: 1) can do it easily, 2) can do it with difficulty, and 3) unable to do it. This paper uses the following algorithm initially developed for the RAND Medical Outcome Study (Stewart et al., 1990):

$$
\text { Health }=(\text { Score }- \text { Min Score }) /(\text { Max Score }- \text { Min Score })
$$

The index takes on a value of 1 if the individual is completely healthy (i.e., he or she can perform all ADLs without difficulty). The index value of zero, on the contrary, indicates the opposite extreme case, which appears to be unusual in the sample of this paper. The regression results show that the coefficients on the aspirations gap are greater than the ones in the previous models, but the results are consistent with the previous findings (Model 2 and 4). Unlike the illness duration, however, there is no evidence that changes in health condition of household head affects the schooling of children. Overall, Table 6 shows that results of this paper are again robust to alternative models controlling for health shocks.

\subsection{Changes in the Aspirations Gap and Schooling of Children}

The previous estimation models presented test results on our first null hypothesis that the aspirations gap of a parent has no effect on schooling of children. The aspirations gap, however, is likely to change over time. Moreover, studies in the literature suggest that the increase in the aspirations gap is influenced both by positive and negative events such as income growth and health shocks (Easterlin, 2001; Czaika \& Vothkneht, 2014; Lim, 2018, 2019). ${ }^{17}$ For instance, Lim (2019) finds that chronic illness negatively affects the way individuals view their current standard of living relative to others and to their future reference points, hence increasing the aspirations gap. Our sample data also show that the increase in the aspirations gap of household heads is influenced by positive and negative shocks such as family income growth, health shocks, and natural disasters (See Appendix Table 9). The marginal effects of increasing aspirations on important decisions such as investment, hence, are ambiguous and need to be identified with data.

In this section, we seek to find an answer to whether an increasing aspirations gap of household heads affects the investment in children's human capital. Unlike the previous models, we control for individual fixed effects in all models in Table 7. The results show that an increase in the aspirations gap is negatively associated with the schooling of children. The effects are statistically significant at the $p<0.01$ level in all models that use the whole sample (model 1 and 2), whether the model uses absolute education years or relative

\footnotetext{
17 According to the adaptation theory that has been developed by Easterlin (2001), aspirations are more likely to be affected by positive changes in income as aspirations adapt to income growth over time. The aspirations gap may also increase as an individual's cognitive neighborhood changes, for instance, in a migration destination (Czaika and Vothkneht, 2014; Lim, 2018). Migrants may even be trapped on a 'hedonic treadmill despite economic benefits in their migration destinations (Czaika and Vothkneht, 2014).
} 


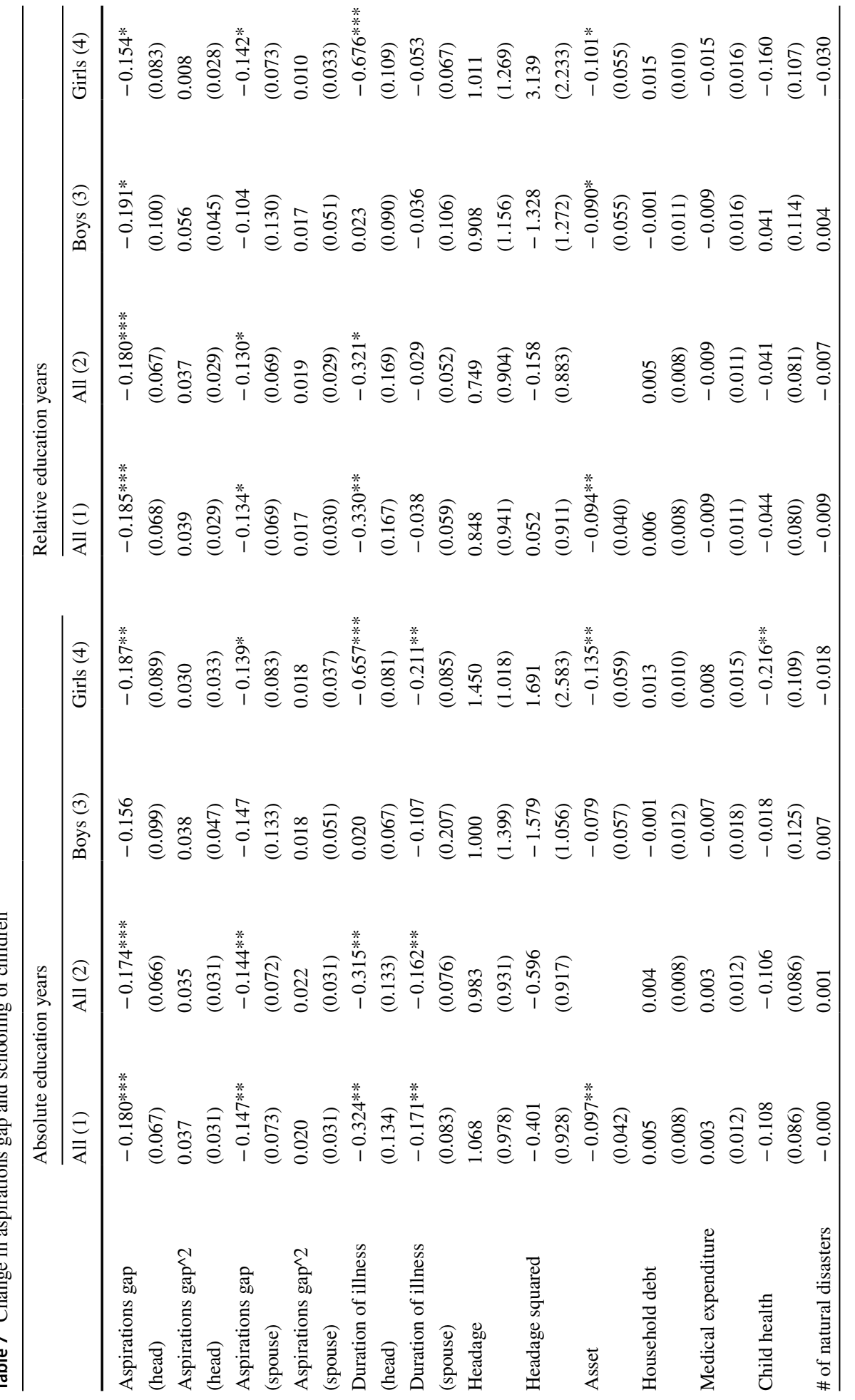




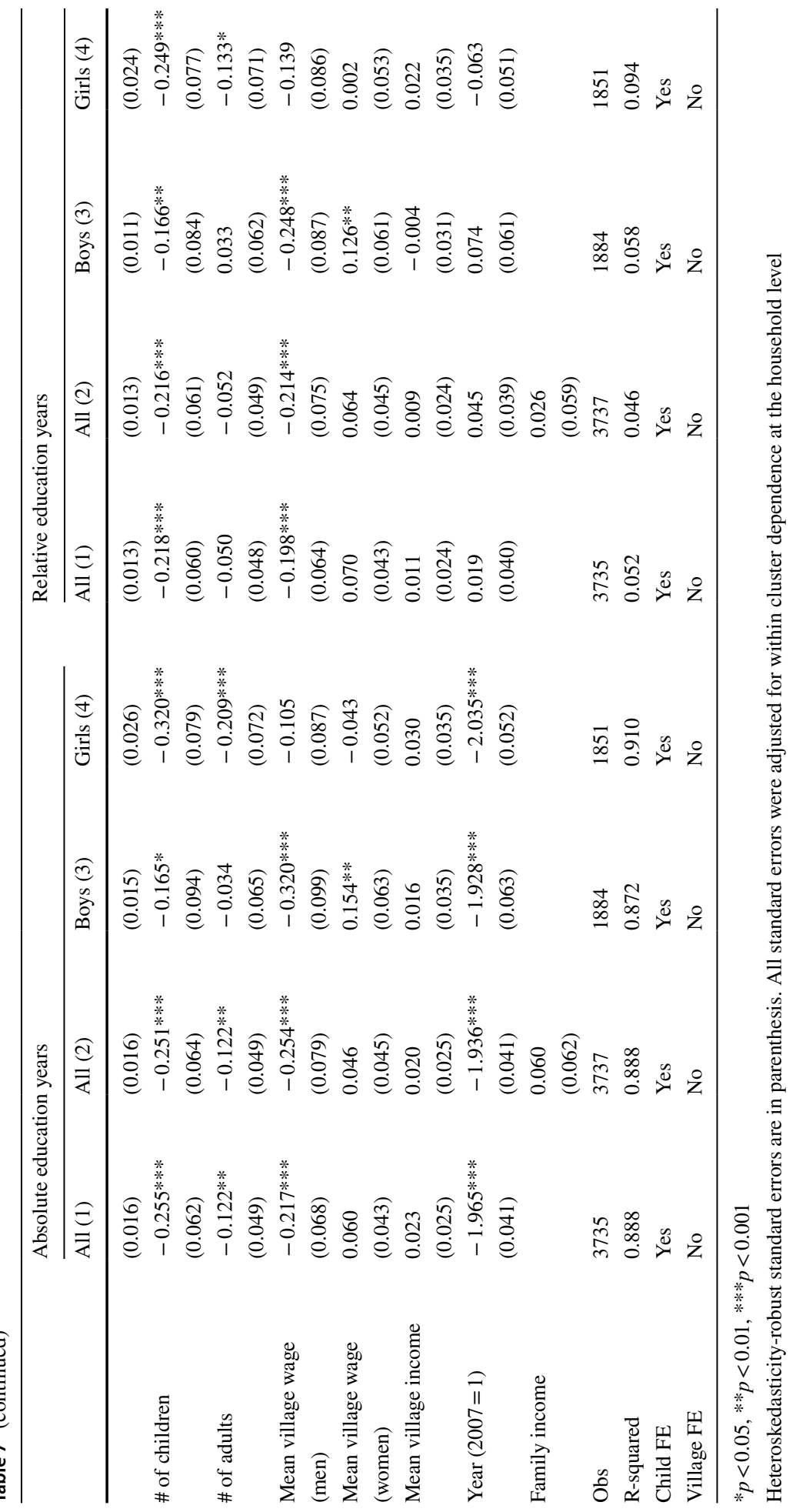


Table 8 Change in aspirations gap and schooling of children (The rich vs. The poor)

\begin{tabular}{|c|c|c|c|c|c|c|}
\hline & All (1) & All (2) & Boys (3) & Boys (4) & Girls (5) & Girls (6) \\
\hline & Bottom $50 \%$ & Top 50\% & Bottom $50 \%$ & Top 50\% & Bottom 50\% & Top 50\% \\
\hline \multicolumn{7}{|c|}{ Absolute education years } \\
\hline $\begin{array}{l}\text { Aspirations gap } \\
\text { (head) } 2007\end{array}$ & $\begin{array}{l}-0.391 * * * \\
(0.114)\end{array}$ & $\begin{array}{l}-0.076 \\
(0.096)\end{array}$ & $\begin{array}{l}-0.375^{* *} \\
(0.173)\end{array}$ & $\begin{array}{l}-0.041 \\
(0.146)\end{array}$ & $\begin{array}{l}-0.423 * * \\
(0.179)\end{array}$ & $\begin{array}{l}-0.106 \\
(0.133)\end{array}$ \\
\hline $\begin{array}{l}\text { Aspirations gap^ } 2 \\
\text { (head) } 2007\end{array}$ & $\begin{array}{l}-0.098 \\
(0.148)\end{array}$ & $\begin{array}{l}-0.067 \\
(0.093)\end{array}$ & $\begin{array}{l}-0.119 \\
(0.229)\end{array}$ & $\begin{array}{l}-0.239 * \\
(0.134)\end{array}$ & $\begin{array}{l}-0.131 \\
(0.168)\end{array}$ & $\begin{array}{l}0.057 \\
(0.134)\end{array}$ \\
\hline $\begin{array}{l}\text { Aspirations gap } \\
\text { (spouse) } 2007\end{array}$ & $\begin{array}{l}0.098 * \\
(0.052)\end{array}$ & $\begin{array}{l}0.011 \\
(0.037)\end{array}$ & $\begin{array}{l}0.094 \\
(0.072)\end{array}$ & $\begin{array}{l}0.046 \\
(0.061)\end{array}$ & $\begin{array}{l}0.101 \\
(0.068)\end{array}$ & $\begin{array}{l}-0.021 \\
(0.050)\end{array}$ \\
\hline $\begin{array}{l}\text { Aspirations gap^2} \\
\text { (spouse) } 2007\end{array}$ & $\begin{array}{l}0.022 \\
(0.057)\end{array}$ & $\begin{array}{l}-0.062 \\
(0.042)\end{array}$ & $\begin{array}{l}0.022 \\
(0.091)\end{array}$ & $\begin{array}{l}-0.032 \\
(0.042)\end{array}$ & $\begin{array}{l}0.021 \\
(0.066)\end{array}$ & $\begin{array}{l}-0.086 \\
(0.061)\end{array}$ \\
\hline \multicolumn{7}{|c|}{ Relative education years } \\
\hline $\begin{array}{l}\text { Aspirations gap } \\
\text { (head) } 2007\end{array}$ & $\begin{array}{l}-0.330 * * * \\
(0.120)\end{array}$ & $\begin{array}{l}-0.093 \\
(0.100)\end{array}$ & $\begin{array}{l}-0.366^{* *} \\
(0.175)\end{array}$ & $\begin{array}{l}-0.084 \\
(0.147)\end{array}$ & $\begin{array}{l}-0.264 * \\
(0.149)\end{array}$ & $\begin{array}{l}-0.086 \\
(0.127)\end{array}$ \\
\hline $\begin{array}{l}\text { Aspirations gap^ } 2 \\
\text { (head) } 2007\end{array}$ & $\begin{array}{l}-0.162 \\
(0.139)\end{array}$ & $\begin{array}{l}-0.039 \\
(0.110)\end{array}$ & $\begin{array}{l}-0.110 \\
(0.205)\end{array}$ & $\begin{array}{l}-0.239 \\
(0.149)\end{array}$ & $\begin{array}{l}-0.223 \\
(0.160)\end{array}$ & $\begin{array}{l}0.113 \\
(0.125)\end{array}$ \\
\hline $\begin{array}{l}\text { Aspirations gap } \\
\text { (spouse) } 2007\end{array}$ & $\begin{array}{l}0.088 * \\
(0.053)\end{array}$ & $\begin{array}{l}0.010 \\
(0.040)\end{array}$ & $\begin{array}{l}0.113 \\
(0.074)\end{array}$ & $\begin{array}{l}0.058 \\
(0.068)\end{array}$ & $\begin{array}{l}0.033 \\
(0.060)\end{array}$ & $\begin{array}{l}-0.040 \\
(0.045)\end{array}$ \\
\hline $\begin{array}{l}\text { Aspirations gap^2 } \\
\text { (spouse) } 2007\end{array}$ & $\begin{array}{l}0.033 \\
(0.050)\end{array}$ & $\begin{array}{l}-0.048 \\
(0.051)\end{array}$ & $\begin{array}{l}0.014 \\
(0.084)\end{array}$ & $\begin{array}{l}0.035 \\
(0.050)\end{array}$ & $\begin{array}{l}0.039 \\
(0.052)\end{array}$ & $\begin{array}{l}-0.097 * \\
(0.056)\end{array}$ \\
\hline
\end{tabular}

Standard errors are in parenthesis. All models include the same control variables used in the previous models

$* * * p<0.01, * * p<0.05, * p<0.1$

education years for the dependent variable. The effects become weakened when the sample is disaggregated into boys and girls, but relative education years are still significantly associated with the schooling of both boys and girls $(P<0.1)$. Spouses' aspirations gap shows similar results, but coefficients are smaller and the effects are only weakly significant on the relative education years $(P<0.1)$. The negative effects of the increasing aspirations gap seem to be consistent with the lower educational attainment of children in the poorer families, of which heads and spouses show a much larger increase in the aspirations gap than the richer between 2007 and 2014 in Indonesia. The results also seem to be in line with the fact that the poor are more vulnerable to adverse shocks to household economy such as health shocks and natural disasters, which are believed to increase the aspirations gap in our sample.

To test our conjecture that the increasing aspirations gap of the poor has a more adverse effect on the investment in children's human capital, we ran additional regressions by disaggregating the sample by the asset level (top 50\% vs. bottom 50\%). The results are presented in Table 8. Overall, the results appear to support our conjecture. In all models, there is no evidence that the schooling of children is affected by the increasing aspirations gap of household heads or their spouses in the top 50\% house asset level. In contrast, the increasing aspirations gap of household heads in poorer households appears to impede the schooling of both boys and girls in all models. The aspirations gap of spouses also appears to affect the schooling of children, but the effect is only weakly significant at the $P<0.1$ level, and the effect becomes insignificant in the models using the subgroup of boys and girls. 


\section{Conclusion}

Under the paradigm of the neoclassical economics, persistent poverty is driven by constraints that are only external to individuals in the form of resource constraints. This paper sheds light on the role of internal constraints in perpetuating poverty traps by examining the link between the aspirations gap of parents and educational attainment of children in Indonesia. Our results show that future reference points that are moderately higher than parents' current life evaluation have positive effects on investment in children's human capital, while an excessive aspirations gap appears to discourage the investment. The results are consistent with the recent aspirations theory that illuminates the social aspects of aspirations formations (Genicot \& Ray, 2017).

Furthermore, the finding that only the schooling of boys is affected by the aspirations gap of household heads is consistent with a general phenomenon of gender bias in human capital investment in developing countries. The linkage of gender bias to wellbeing aspirations of household heads may be attributed to the greater pecuniary returns that sons provide to their parents relative to daughters in developing countries in South Asia, where sons tend to take care of their old parents (Alderman \& Gertler, 1997; Ebeinstein \& Leung, 2010; Chen et al., 2017; Huang et al, 2017). This conjecture is also consistent with the view that children who receive greater resources are more likely than other siblings to provide assistance to an elderly parent (Frankenberg et al., 2002; Henretta et al., 1997). Future research could explore more to test these conjectures.

Another important finding of this paper is that schooling of children is adversely affected by an increasing aspirations gap of parents. The increase in the aspirations gap is influenced both by positive and negative events, and the reaction of individuals to the change is ambiguous. On the one hand the increase in the aspirations gap could lead to a more forward-looking decision making, but on the other hand it could result in frustration and deterioration of emotional wellbeing, which in turn may lead to underinvestment in human capital. The results of this paper show that the increase in the aspirations gap of parents, ceteris paribus, is associated with a significantly lower schooling attainment of both boys and girls between 2007 and 2014. Interestingly, the adverse effect of the change in parental aspirations gap on children's schooling is significant only in the poor households. This is perhaps due to the fact that the poor tend to be more vulnerable to negative shocks such as natural disasters and health shocks to household heads, which are likely to increase the aspirations gap.

Overall, the findings of this paper provide empirical evidence for a significant role of the aspirations gap of household heads in their children's human capital investment, shedding light on a possible channel through which intergenerational transmission of poverty occurs. The findings are of special interests to policy makers who are concerned about poverty and rising income inequalities in developing countries. Government subsidies on education may help the poor in the vicious cycle of poverty trap, but studies suggest that there exists heterogeneity in the impact of cash transfer programs (Khandker et al., 2003; Glewwe \& Olinto, 2004; Schultz, 2004; Attanasio et al., 2010; Maluccio \& Flores, 2005; Levy \& Ohls, 2010; Filmer \& Schady, 2008; Chaudhury \& Parajuli, 2010). The findings of this paper suggest that benefits of transfer programs may be greater, when policy makers target subsidies towards households with lower relative 
income rather than absolute income especially in communities where income inequality is becoming more severe.

The results of our study also suggest a policy implication for improving girls' educational outcome in Indonesia. Our results show that parental aspirations have little effect on investment in girls' human capital. More resources may be allocated on boys' education due to a cultural influence or perception of lower returns to girls' education in Indonesia, which makes it challenging to derive effective and affordable policy implications. The findings of this paper suggests that public policies designed to change the view of parents on the value of girls' education may be more effective than other policies. For instance, admirable female leaders nearby can influence the aspirations of girls and parents by opening their aspirational window (Beaman et al., 2012). Thus, laws can help to create such role models by opening opportunities for women in more leadership positions, which is likely to be less costly than other policies such as providing educational subsidies for girls. This kind of policy change can of course be combined with targeted cash-transfer programs.

As a final remark, the findings of this study should be interpreted with some caution.

The empirical methodologies adopted in this study control for confounding factors at the.

individual and village levels. Nevertheless, they may not be completely free of the biases associated with unobservable village characteristics that change over time, given the long interval between the 2007 and 2014. Also, while we take into account the possible feedback effects of schooling of children in our empirical models, an instrumental variable could be used to address the reverse causality issue and confirm our findings. However, finding a good instrumental variable is always challenging, and we were not able to find a good variable in our data. Further research is needed in different institutional settings to corroborate our findings in this study.

\section{Appendix}

See Table 9. 


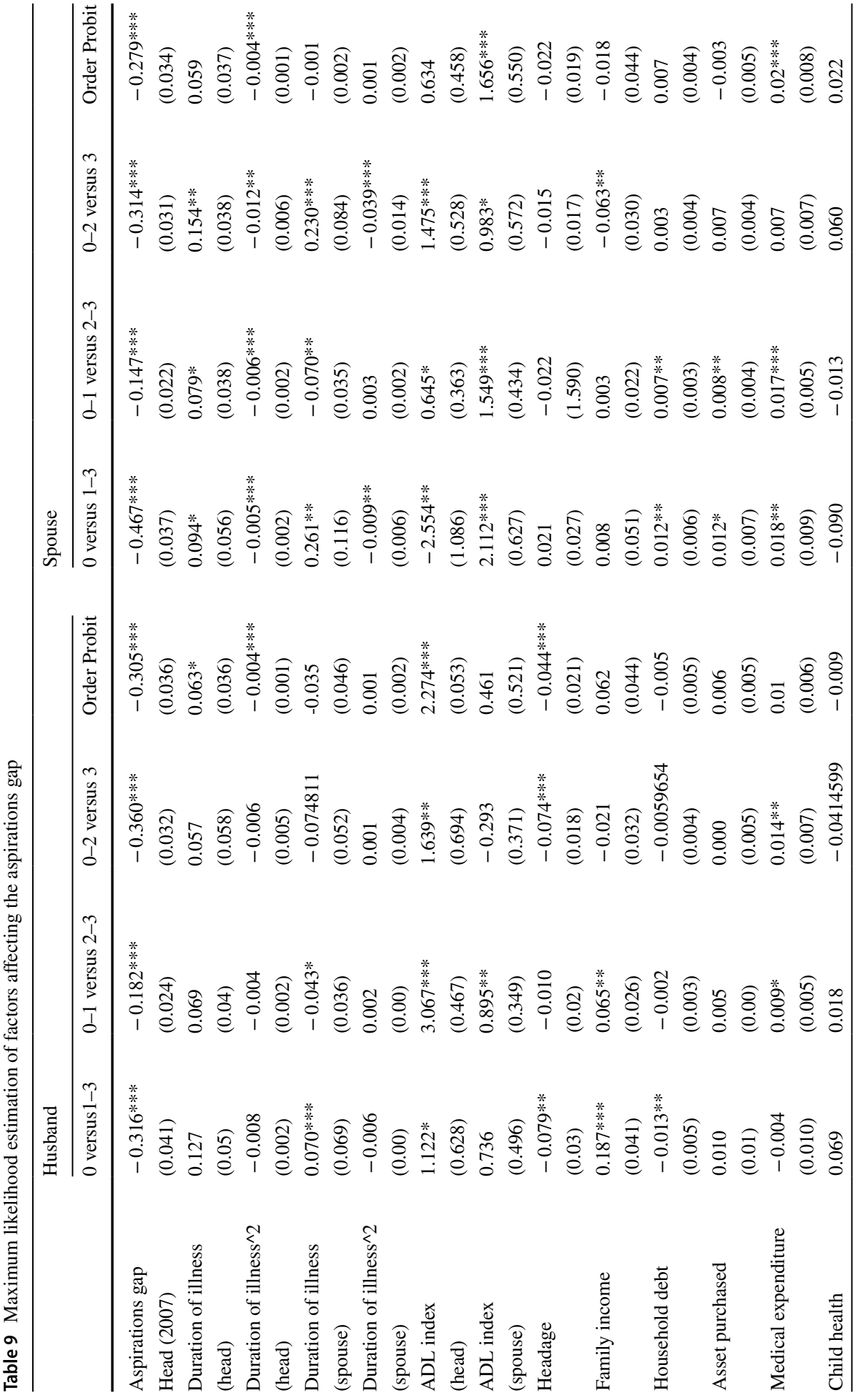




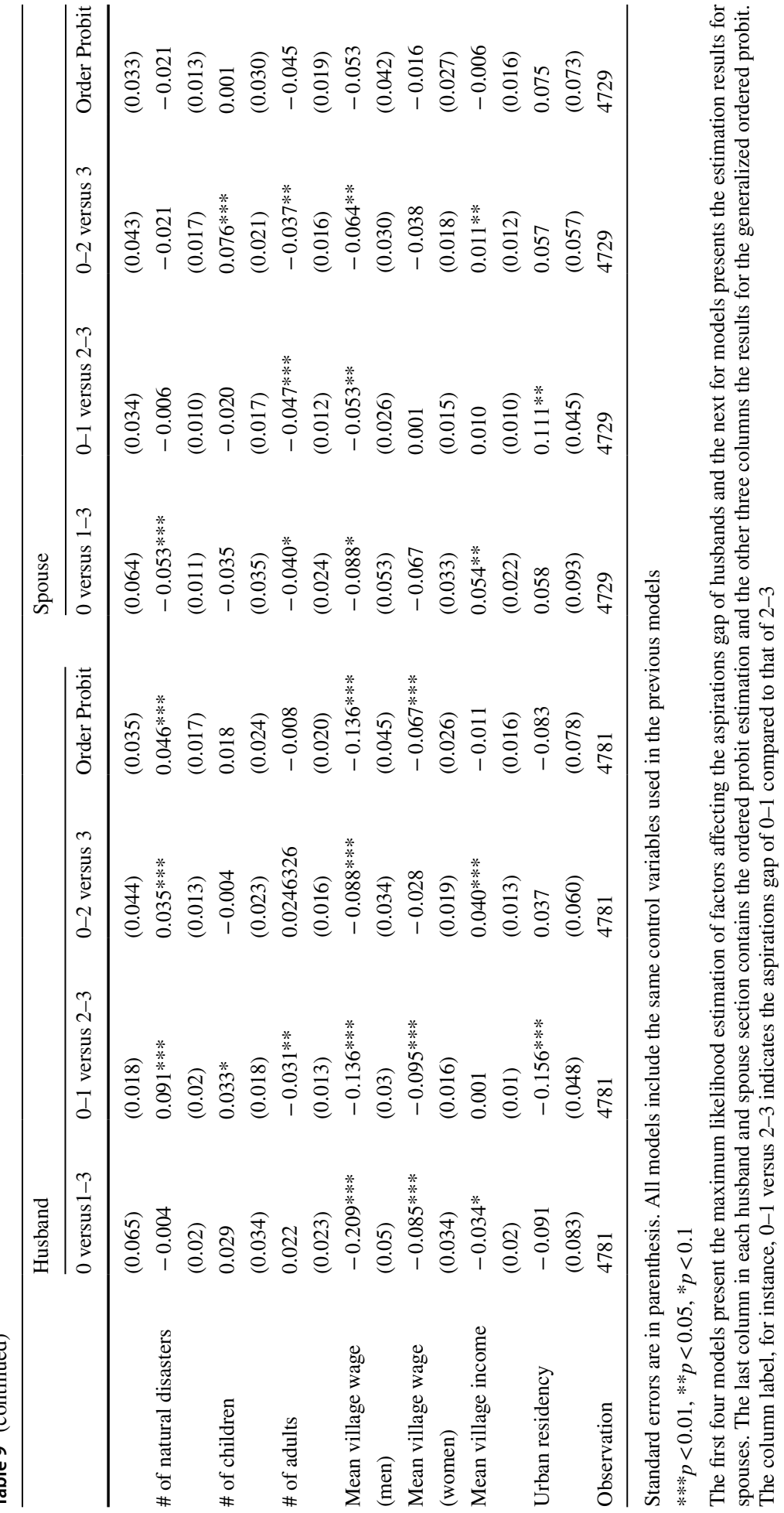


Open Access This article is licensed under a Creative Commons Attribution 4.0 International License, which permits use, sharing, adaptation, distribution and reproduction in any medium or format, as long as you give appropriate credit to the original author(s) and the source, provide a link to the Creative Commons licence, and indicate if changes were made. The images or other third party material in this article are included in the article's Creative Commons licence, unless indicated otherwise in a credit line to the material. If material is not included in the article's Creative Commons licence and your intended use is not permitted by statutory regulation or exceeds the permitted use, you will need to obtain permission directly from the copyright holder. To view a copy of this licence, visit http://creativecommons.org/licenses/by/4.0/.

\section{References}

Alderman, H., \& Gertler, P. (1997). Family resources and gender differences in human capital investments: The demand for children's medical care in Pakistan, in Intrahousehold resource allocation in developing countries: Methods, models, and policy (pp. 231-248). John Hopkins University Press.

Appadurai, A. (2004). The capacity to aspire. Culture and Public Action, 59-84.

ASEAN. (2014). ASEAN state of education report 2013. ASEAN Secretariat, Jakarta, Indonesia.

Attanasio, O., Fitzsimons, E., Gomez, A., Gutierrez, M. I., Meghir, C., \& Mesnard, A. (2010). Children's schooling and work in the presence of a conditional cash transfer program in rural Colombia. Economic Development and Cultural Change, 58, 181-210.

Banerjee, A. V., \& Newman, A. F. (1991). Risk-bearing and the theory of income distribution. The Review of Economic Studies, 58, 211-235.

Banerjee, A. V., \& Newman, A. F. (1993). Occupational choice and the process of development. Journal of Political Economy, 101, 274-298.

Bardhan, P. (1997). Corruption and development: a review of issues. Journal of economic literature, 35(3), $1320-1346$.

Barro, R. J., \& Lee, J. W. (2013). A new data set of educational attainment in the world, 1950-2010. Journal of Development Economics, 104, 184-198.

Becker, G. S. (1960). An economic analysis of fertility. In demographic and economic change in developed Countries. Columbia University Press.

Becker, G. S., \& Lewis, H. G. (1973). On the interaction between the quantity and quality of children. Journal of Political Economy, 81, S279-S288.

Becker, G. S., \& Tomes, N. (1976). Child endowments and the quantity and quality of children. Journal of Political Economy, 84, S143-S162.

Beaman, L., Duflo, E., Pande, R., \& Topalova, P. (2012). Female leadership raises aspirations and educational attainment for girls: A policy experiment in India. Science, 335(6068), 582-586.

Becker, G. S., Murphy, K. M., \& Tamura, R. (1990). Human capital, fertility, and economic growth. Journal of Political Economy, 98(5, Part 2), S12-S37.

Behrman, J. R. (1992). Intrahousehold allocation of nutrients and gender effects: A survey of structural and reduced form estimates. In S. Osmani (Ed.), Nutrition and Poverty. Oxford: Oxford University.

Bloom, D. E., Sachs, J. D., Collier, P., \& Udry, C. (1998). Geography, demography, and economic growth in Africa. Brookings Papers on Economic Activity, 1998(2), 207-295.

Bowles, S., \& Gintis, H. (1976). Schooling in capitalist America (Vol. 57). Basic Books.

Bowles, S., \& Gintis, H. (2002). The inheritance of inequality. Journal of Economic Perspectives, 16(3), 3-30.

Carter, M. R., \& Barrett, C. B. (2006). The economics of poverty traps and persistent poverty: An assetbased approach. The Journal of Development Studies, 42, 178-199.

Carter, M. R., \& Lybbert, T. J. (2012). Consumption versus asset smoothing: Testing the implications of poverty trap theory in Burkina Faso. Journal of Development Economics, 99, 255-264.

Chaudhury, N., \& Parajuli, D. (2010). Conditional cash transfers and female schooling: The impact of the female school stipend programme on public school enrolments in Punjab, Pakistan. Applied Economics, 42, 3565-3583.

Chen, S. H., Chen, Y.-C., \& Liu, J.-T. (2017). The impact of family composition on educational achievement. The Journal of Human Resources, Advanced Online Publication, . https://doi.org/10.3368/jhr. 54.1.0915.7401R1 
Chiapa, C., Garrido, J. L., \& Prina, S. (2012). The effect of social programs and exposure to professionals on the educational aspirations of the poor. Economics of Education Review, 31, 778-798.

Chivers, D. (2017). Success, survive or escape? Aspirations and poverty traps. Journal of Economic Behavior \& Organization, 143, 116-132.

Colbran, N. (2010). Realities and challenges in realising freedom of religion or belief in Indonesia. The International Journal of Human Rights, 14(5), 678-704.

Czaika, M., \& Vothknecht, M. (2014). Migration and aspirations-are migrants trapped on a hedonic treadmill? IZA Journal of Migration, 3(1), 1-21.

Dalton, P. S., Ghosal, S., \& Mani, A. (2016). Poverty and aspirations failure. The Economic Journal, 126, 165-188.

Dasgupta, P., \& Ray, D. (1986). Inequality as a determinant of malnutrition and unemployment: Theory. The Economic Journal, 96, 1011-1034.

Dasgupta, S., Deichmann, U., Meisner, C., \& Wheeler, D. (2005). Where is the poverty-environment nexus? Evidence from Cambodia, Lao PDR, and Vietnam. World Development, 33, 617-638.

Dercon, S., \& Christiaensen, L. (2011). Consumption risk, technology adoption and poverty traps: Evidence from Ethiopia. Journal of Development Economics, 96, 159-173.

Duncan, G. J., Brooks-Gunn, J., \& Klebanov, P. K. (1994). Economic deprivation and early childhood development. Child Development, 65(2), 296-318.

Duncan, G. J., \& Brooks-Gunn, J. (Eds.). (1997). Income effects across the life span: Integration and interpretation. In Consequences of growing up poor (pp. 596-610) New York: Russell Sage Foundation.

Durlauf, S. N. (2004). Neighborhood effects. Handbook of Regional and Urban Economics, 4, 2173-2242.

Easterlin, R. A. (2001). Income and happiness: Towards a unified theory. The Economic Journal, 111, 465-484.

Ebenstein, A., \& Leung, S. (2010). Son preference and access to social insurance: Evidence from China's rural pension program. Population and Development Review, 36, 47-70.

Filmer, D., \& Schady, N. (2008). Getting girls into school: Evidence from a scholarship program in Cambodia. Economic Development and Cultural Change, 56, 581-617.

Frankenberg, E., Lillard, L., \& Willis, R. J. (2002). Patterns of intergenerational transfers in Southeast Asia. Journal of Marriage and Family, 64(3), 627-641.

Galab, S., Vennam, U., Komanduri, A., Benny, L., \& Georgiadis, A. (2013). The impact of parental aspirations on private school enrolment: Evidence from Andhra Pradesh.

Galor, O., \& Zeira, J. (1993). Income distribution and macroeconomics. The Review of Economic Studies, 60, 35-52.

Genicot, G., \& Ray, D. (2017). Aspirations and inequality. Econometrica, 85, 489-519.

Glaeser, A. A., \& Sacerdote, B. (2001). Why Doesn't the US Have a European Style Welfare State?. Brookings Papers on Economic Activity, Fall.

Glewwe, P. \& Olinto, P. (2004). Evaluating the impact of conditional cash transfers on schooling: An experimental analysis of Honduras' PRAF program. Unpublished manuscript, University of Minnesota.

Henretta, J. C., Hill, M. S., Li, W., Soldo, B. J., \& Wolf, D. A. (1997). Selection of children to provide care: The effect of earlier parental transfers. Journals of Gerontology Series B, 52, 110-119.

Herrnstein, R. J. (1995). The Bell Curve Debate: History, Documents, Opinions. R. Jacoby, \& N. Glauberman (Eds.). New York: Times Books.

Hoff, K., \& Sen, A. (2005). Homeownership, community interactions, and segregation. American Economic Review, 95(4), 1167-1189.

Huang, F., Jin, G. Z., \& Xu, L. C. (2017). Love, money, and old age support: Does parental matchmaking matter? Journal of Comparative Economics, 45, 224-245.

Jacoby, H. G., \& Skoufias, E. (1997). Risk, financial markets, and human capital in a developing country. The Review of Economic Studies, 64, 311-335.

Janzen, S. A., Magnan, N., Sharma, S., \& Thompson, W. M. (2017). Aspirations failure and formation in rural Nepal. Journal of Economic Behavior \& Organization, 139, 1-25.

Jensen, R. (2010). The (perceived) returns to education and the demand for schooling. The Quarterly Journal of Economics, 125, 515-548.

Jensen, R. (2012). Do labor market opportunities affect young women's work and family decisions? Experimental evidence from India. The Quarterly Journal of Economics, 127, 753-792.

Khandker, S., Pitt, M., \& Fuwa, N. (2003). Subsidy to promote girls' secondary education: the female stipend program in Bangladesh.

Kahneman, D., \& Tversky, A. (1979). Prospect theory: An analysis of decision under risk. Econometrica, 47, 263-291. 
Klasen, S. (2002). Low schooling for girls, slower growth for all? Cross-country evidence on the effect of gender inequality in education on economic development. The World Bank Economic Review, 16, $345-373$.

Kőszegi, B., \& Rabin, M. (2006). A model of reference-dependent preferences. Quarterly Journal of Economics, $121,1133-1165$.

Kremer, M. (1993). The O-ring theory of economic development. The Quarterly Journal of Economics, $108,551-575$.

Lareau, A. (2000). Home advantage: Social class and parental intervention in elementary education. Rowman \& Littlefield Publishers.

Lareau, A. (2011). Unequal childhoods: Class, race, and family life. Univ of California Press.

Levy, D., \& Ohls, J. (2010). Evaluation of Jamaica's PATH conditional cash transfer programme. Journal of Development Effectiveness, 2, 421-441.

Lim, S. S. (2018). Aspirations of migrants and returns to human capital investment. Social Indicators Research, 138, 317-334.

Lim, S. S. (2019). The effects of chronic illness on aspirations and subjective wellbeing. Journal of Happiness Studies, 21, 1-23.

Loury, G. C. (1981). Intergenerational transfers and the distribution of earnings. Econometrica: Journal of the Econometric Society, 49, 843-867.

Ma, C., \& Schapira, M. (2017). The Bell Curve: Intelligence and Class Structure in American Life. Macat Library.

Macours, K., \& Vakis, R. (2014). Changing households' investment behaviour through social interactions with local leaders: Evidence from a randomised transfer programme. The Economic Journal, 124, 607-633.

Maluccio, J. \& Flores, R. (2005). Impact evaluation of a conditional cash transfer program: The Nicaraguan Red de Protección Social. Intl Food Policy Res Inst.

Miller, B. D. (1997). Social class, gender and intrahousehold food allocations to children in South Asia. Social Science \& Medicine, 44, 1685-1695.

Murthi, M., Guio, A.-C., \& Dreze, J. (1995). Mortality, fertility, and gender bias in India: A district-level analysis. Population and Development Review, 21, 745-7824.

Nguyen, T. (2008). Information, role models and perceived returns to education: Experimental evidence from Madagascar. Unpublished manuscript 6.

Oketch, M., Mutisya, M., \& Sagwe, J. (2012). Parental aspirations for their children's educational attainment and the realisation of universal primary education (UPE) in Kenya: Evidence from slum and nonslum residences. International Journal of Educational Development, 32, 764-772.

Pasquier-Doumer, L., \& Brandon, F. R. (2015). Aspiration failure: A poverty trap for indigenous children in Peru? World Development, 72, 208-223.

Purnastuti, L., Salim, R., \& Joarder, M. A. M. (2015). The returns to education in Indonesia: Post reform estimates. The Journal of Developing Areas, 49, 183-204.

Ranjan, P. (2001). Credit constraints and the phenomenon of child labor. Journal of Development Economics, 64, 81-102.

Raut, L. K. (1990). Capital accumulation, income distribution and endogenous fertility in an overlapping generations general equilibrium model. Journal of Development Economics, 34(1-2), 123-150.

Raut, L. K., \& Tran, L. H. (2005). Parental human capital investment and old-age transfers from children: Is it a loan contract or reciprocity for Indonesian families? Journal of Development Economics, 77(2), $389-414$.

Ray, D. (2006). Aspirations, poverty, and economic change. Understanding Poverty.

Ross, P. H. (2017). The Aspirations Gap and Human Capital Investment: Evidence from Indian Adolescents. mimeo, Boston University.

Rosser, A., \& Joshi, A. (2013). From user fees to fee free: The politics of realising universal free basic education in Indonesia. The Journal of Development Studies, 49(2), 175-189.

Schultz, T. P. (2004). School subsidies for the poor: Evaluating the Mexican Progresa poverty program. Journal of Development Economics, 74, 199-250.

Sen, A. (1990). More than 100 million women are missing. New York, 61-66.

Sen, K. H. (2006). The kin system as a poverty trap? Poverty Traps, 95.

Shalev, J. (2000). Loss aversion equilibrium. International Journal of Game Theory, 29(2), 269-287.

Shavit, Y., \& Blossfeld, H. P. (1993). Persistent Inequality: Changing Educational Attainment in Thirteen Countries. Social Inequality Series. Westview Press, 5500 Central Avenue, Boulder, CO 80301-2847.

Shleifer, A., \& Vishny, R. W. (1993). Corruption. The Quarterly Journal of Economics, 108, 599-617.

Strauss, J., \& Thomas, D. (1998). Health, nutrition, and economic development. Journal of Economic Literature, 36(2), 766-817. 
Thomas, D. (1990). Intra-household resource allocation: An inferential approach. Journal of Human Resources, 25, 635-664.

World Bank, 2017. World Development Indicators.

World Bank, 2018. Indonesia Economic Quarterly, September 2018: Urbanization for All. World Bank.

Publisher's Note Springer Nature remains neutral with regard to jurisdictional claims in published maps and institutional affiliations. 